\title{
Capital Requirements, Risk Choice, and Liquidity Provision in a Business Cycle Model
}

\section{Citation}

Begenau, Juliane. "Capital Requirements, Risk Choice, and Liquidity Provision in a Business Cycle Model." Harvard Business School Working Paper, No. 15-072, March 2015.

\section{Permanent link}

http://nrs.harvard.edu/urn-3:HUL.InstRepos:14369105

\section{Terms of Use}

This article was downloaded from Harvard University's DASH repository, and is made available under the terms and conditions applicable to Open Access Policy Articles, as set forth at http:// nrs.harvard.edu/urn-3:HUL.InstRepos:dash.current.terms-of-use\#OAP

\section{Share Your Story}

The Harvard community has made this article openly available.

Please share how this access benefits you. Submit a story.

\section{Accessibility}




\section{Capital Requirements, Risk Choice, and Liquidity Provision in a Business Cycle Model}

Juliane Begenau

Working Paper 15-072 


\title{
Capital Requirements, Risk Choice, and Liquidity Provision in a Business Cycle Model
}

\author{
Juliane Begenau
}

Harvard Business School

Working Paper 15-072 


\title{
Capital Requirements, Risk Choice, and Liquidity Provision in a Business Cycle Model
}

\author{
Juliane Begenau* \\ Harvard Business School
}

March 7, 2015

\begin{abstract}
This paper develops a quantitative dynamic general equilibrium model in which households' preferences for safe and liquid assets constitute a violation of Modigliani and Miller. I show that the scarcity of these coveted assets created by increased bank capital requirements can reduce overall bank funding costs and increase bank lending. I quantify this mechanism in a two-sector business cycle model featuring a banking sector that provides liquidity and has excessive risk-taking incentives. Under reasonable parametrizations, the marginal benefit of higher capital requirements related to this channel significantly exceeds the marginal cost, indicating that US capital requirements have been sub-optimally low.
\end{abstract}

Keywords: Capital Requirements, Bank Lending, Safe Assets, Macro-Finance JEL codes: E32, E41, E51, G21, G28

${ }^{*}$ I am deeply indebted to Monika Piazzesi, Martin Schneider, and Pablo Kurlat for their invaluable guidance and patience. I also thank Malcolm Baker, Laurent Clerc, Theresa Kuchler, Moritz Lenel, David Scharfstein, Dmitriy Sergeyev, Erik Stafford, Jeremy Stein, and Adi Sunderam for helpful comments. Numerous seminar participants at Stanford, St. Louis Fed, Duke Fuqua, Richmond Fed, UCLA Anderson, USC Marshall, Boston Fed, Harvard Business School, Minnesota Carlson, Chicago, Northwestern, Berkeley Haas, Columbia Business School, NYU Stern, New York Fed, the EUI conference on Macroeconomic Stability, Bocconi, and Wharton provided insightful comments. Support by the Macro Financial Modeling Group dissertation grant from the Alfred P. Sloan Foundation and the Kohlhagen Fellowship Fund, as well as the Haley-Shaw Fellowship Fund of the Stanford Institute for Economic Policy Research (SIEPR), is gratefully acknowledged. Email: jbegenau@hbs.edu. 


\section{Introduction}

A central policy question is how to set the capital requirements for banks. Previous work has suggested that there is a trade-off: higher capital requirements increase the stability of banks but come at the cost of reduced loan and liquidity provision by banks. Using a quantitative general equilibrium model, this paper calls into question the cost with regard to lending.

The main proposition is that higher capital requirements leading to a reduction in the supply of bank debt can in fact result in more lending. The core assumption is that investors value safe and liquid assets in the form of bank debt more the scarcer they become. As a consequence, in general equilibrium interest rates on bank debt adjust downwards when the aggregate supply of bank debt decreases. This can lead to a reduction in the funding costs of banks and to an expansion of credit.

Figure 1 provides suggestive evidence for the core assumption that bank debt is priced at a premium for its safety and liquidity. ${ }^{1}$ The figure presents the yield spread between Aaa-rated corporate bonds and the implied interest rate on bank debt against the bank debt-to-GDP ratio. A lower ratio of bank debt-to-GDP is related to a lower interest rate on bank debt relative to other safe assets, e.g. Aaa corporate bonds. This is akin to a demand function for safe assets in the form of bank debt.

The following numerical example illustrates the main mechanism of the model using its parametrization. $^{2}$ Suppose the banking sector funds assets - loans — with riskless debt and equity. Lending is subject to decreasing returns to scale. Households have a downward sloping demand for safe and liquid assets that the banking sector provides. This demand creates a violation of Modigliani and Miller. The funding costs of loans are a weighted average of debt and equity financing costs. Suppose the weight on equity financing (the capital requirement) is $11 \%$, the annualized interest rate on bank debt is $1.5 \%$, and the cost of equity is $10 \%$ per year. In this case, funding $\$ 1$ of loans costs the bank $2.57 \%$. Now suppose the capital requirement increases to $14 \%$. Without a change in the rate on bank debt, the funding costs of loans increase by $10 \%$ because a larger share of loans has to be financed with relatively more expensive equity. When the return on loans in the banking sector is subject to decreasing returns to scale, banks optimally reduce their loan supply

\footnotetext{
${ }^{1}$ Krishnamurthy and Vissing-Jorgensen (2013) estimate a demand function for Treasuries. They find that Treasuries and bank deposits crowd out the net supply of privately issued short-term debt. This means that households prefer to hold liquid and safe assets provided by regulated banks and by the government over "safe" assets provided by non-regulated private institutions.

${ }^{2}$ In this example, I hold the return on equity constant in order to focus on the effect coming from the endogenous response of the bank debt rate. Generally, an increase in the capital requirement reduces the riskiness of equity and therefore the return on equity.
} 


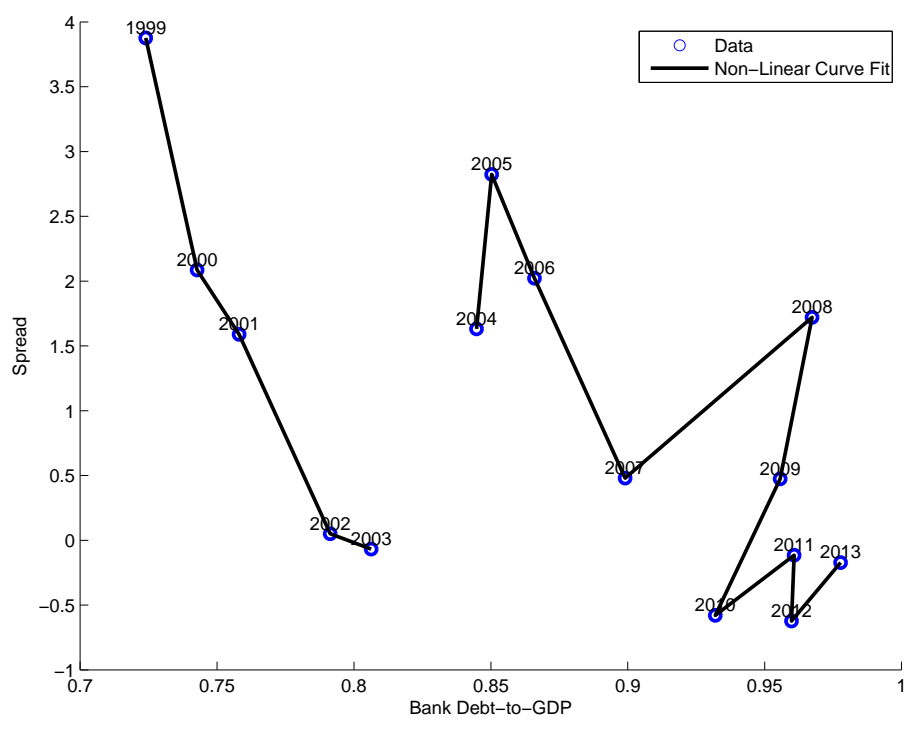

Figure 1: Corporate bond spread and bank debt. The figure plots the spread between the Aaa corporate bond rate and the implied interest rate on bank debt adjusted for the termspread between a twenty year and a one year zero-coupon treasury bond (y axis) against the bank debt-to-GDP ratio (x axis) on the basis of annual observations from 1999 to 2013. This period reflects a deregulated banking system that arguably started with the passing of the Gramm-Leach-Bliley Act in 1999.

to break even (the familiar result in the literature) and contract their debt by $9 \%$. The reduction in the aggregate supply of bank debt increases its desirability to households as it represents an upward movement along the demand schedule for safe assets. As a result, the interest rate on bank debt falls to $0.88 \%,{ }^{3}$ and the funding costs of banks fall to $2.15 \%$. Lower funding costs motivate banks to increase lending by $2.12 \%$.

At first glance, the positive effect on lending appears to be contrary to the evidence; see for instance the study by Peek and Rosengren (1995). A well identified response in bank lending to a change in capital regulation can only be estimated in partial equilibrium. ${ }^{4}$ This is why it is useful to study the trade-offs of capital regulation in a quantitative general equilibrium framework.

I build upon a standard two-sector business cycle model in which households have a preference for safe and liquid assets in the form of bank debt. This is a simple way to introduce a demand for bank debt and is akin to a money-in-the-utility function specification. The model furthermore features a banking sector that makes risky and productive investments for a subset of production and creates safe assets in the form of bank debt, such as

\footnotetext{
${ }^{3}$ The reduction in the riskless rate is solely driven by the demand channel as bank debt is risk-free before and after the increase in the requirement because of implicit or explicit government guarantees.

${ }^{4} \mathrm{My}$ model is consistent with studies that identify a negative response of lending to increases in the capital requirement when prices do not adjust.
} 
deposits, as well as government subsidies that encourage banks to take excessive risks. The model captures the business cycle dynamics of the banking sector as well as macroeconomic aggregates. Calibrating the model, I find that the capital requirement should be $14 \%$ of risky assets. This level trades off the reduced supply of safe and liquid assets in the form of bank debt against a lower output volatility and an increased loan supply.

In the model, the banking sector chooses how much credit to extend as well as how much risk and leverage to take on. An implicit government guarantee ${ }^{5}$ makes bank debt a safe investment for households. Bank debt is priced at a discount because households value the safety and liquidity it provides. Consequently, the Modigliani-Miller theorem does not hold and banks choose as much leverage as allowed by regulation.

Aside from the positive effect on lending, a higher requirement also benefits the economy through a reduction in volatility. Banks' risk choice weighs the benefit from the subsidy against a loss in efficiency that occurs with sufficiently high risk-taking. When banks decrease leverage, the subsidy is also decreased. This lowers banks' incentives to choose a high amount of risk through the subsidy's complementarity with leverage. Less risk-taking by banks reduces the volatility of total output and raises the efficiency of the banking sector.

To quantify the trade-off, I match the model to data from the National Income and Product Accounts (NIPA) and banks' regulatory filings from the Federal Deposit Insurance Corporation (FDIC) for 1999-2013. The welfare effect depends mainly on two parameters: the sensitivity of the subsidy to risk-taking and the elasticity of households preference for bank debt. In the model, the elasticity determines how much households dislike supply shock driven variations in the bank debt-to-consumption ratio. The greater the elasticity, the greater the response of the interest rate to a reduction in bank debt. I therefore choose this parameter to target the volatility of the ratio of total bank debt to NIPA consumption, attributing all variations to supply shocks. Consequently, I find an elasticity that is likely to be a lower bound. In the model, banks take on more risk when the subsidy (included in profits) is high. I infer the value for the sensitivity of the subsidy to risk-taking by targeting the volatility of banks' income-assets ratio conditional on past profits to the data.

The quantified model matches balance sheet and income statement data from banks together with macroeconomic aggregates. Moreover, its dynamics are consistent with many business cycle moments in the data that have not been targeted. For example, it is consistent with the procyclicality and volatility of the banking sector balance sheet and income statement variables. It also captures the correlations between NIPA and balance sheet variables, which makes it particularly suitable for studying the effects of capital requirements on the economy.

\footnotetext{
${ }^{5}$ The subsidy stems from the inability of the government to commit to not bail out the banking sector.
} 
I use the model to derive the optimal Tier-1 capital requirement based on households' utility. Increasing the requirement to $14 \%$ from the current status quo leads to a reduction in bank debt, an increase in bank lending, and a reduction in the volatility of bank income. Total output and consumption increase by $0.10 \%$ on a quarterly basis. The volatility in the banking sector decreases by 3 percentage points, and bank debt decreases by $2 \%$. The general equilibrium effect reduces banks' borrowing rate by $17 \mathrm{bps}$, leading to a $10 \mathrm{bps}$ fall in total funding costs. Banking sector lending increases by roughly $0.6 \%$, an amount that translates to $\$ 253$ more bank credit per capita and quarter.

\section{Related Literature}

This paper builds on optimal banking regulation theory and dynamic macroeconomic models with financial frictions and intermediaries.

The recent financial crisis has sparked a discussion - motivated by theoretical models - of whether banks' capital requirements should be increased. This relates to the question of why banks are highly leveraged. One strand of the literature presents high leverage ratios as a solution to governance problems (for example Dewatripont and Tirole (1994, 1994a, 2012)), or attributes high leverage ratios to banks' role as liquidity and safe asset providers (for example Gorton and Pennacchi (1990), Gorton and Winton (1995), Diamond and Rajan (2000), Diamond and Rajan (2001), Gorton et al. (2012), DeAngelo and Stulz (2013), and Hanson et al. (2014)). The present model incorporates the role of banks as providers of safe and liquid assets and thus captures the effects of higher capital regulation on liquidity creation.

In contrast to the previous strand of literature, Admati, DeMarzo, Hellwig, and Pfleiderer (2012) argue that equity is costly because of subsidies provided by government guarantees and preferential tax treatment: ${ }^{6}$ higher capital requirements reduce incentives for excessive risk-taking and debt overhang problems. In the present paper, I quantify the potential costs (a lower supply of safe and liquid assets) and benefits (less risk-taking by banks) of a higher requirement that have been identified in the theoretical literature. ${ }^{7}$

Macroeconomics models with financial frictions are rooted in Bernanke and Gertler (1989) and Kiyotaki and Moore (1997). Bernanke, Gertler, and Gilchrist (1999) and Christiano, Motto, and Rostagno (2010) have incorporated credit market imperfections into New Keynesian models. This paper builds on this work and develops a tractable macroeconomic

\footnotetext{
${ }^{6}$ Hanson, Stein, and Kashyap (2010) and Kashyap, Rajan, and Stein (2008) also argue for higher capital requirements referring to the tax-advantage of debt and competitive pressure over cheap funding sources as the leading source for banks' high leverage.

${ }^{7}$ There are several interesting theory papers that study the effect of capital requirements, for example Harris, Opp, and Opp (2014) and Allen and Carletti (2013)
} 
framework with a focus on the effects of capital requirements. It is more closely related to work that quantifies ${ }^{8}$ the effects of capital requirements and leverage constraints, for instance Christiano and Ikeda (2013), Martinez-Miera and Suarez (2014), Van Den Heuvel (2008), Nguyen (2014), De Nicolò et al. (2014), and Corbae and D'Erasmo (2012).

Van Den Heuvel (2008) is one of the first to use a quantitative general equilibrium growth model with liquidity demand of households to assess the effects of capital requirement on welfare. He finds that the main effect of the capital requirement was a reduction in deposits and therefore the current requirement was too high.

Recently, several papers study capital requirements in a quantitative environment; see for example Christiano and Ikeda (2013), Martinez-Miera and Suarez (2014), Corbae and D’Erasmo (2012), De Nicolò et al. (2014), Clerc et al. (2014), and Nguyen (2014). A common feature of these papers is that a tightening of the constraint reduces the riskiness of the banking system but ${ }^{9}$ it also reduces the amount of lending, which results in a lower GDP. In the present model, the effects on risk-taking and lending activities from a change in the capital requirement are still present, but I also incorporate the consequences of a change in the supply of safe and liquid assets. With preferences for safe and liquid bank debt, the tradeoff of a higher requirement with regard to banks' lending activities (in general equilibrium) is reversed: when households value bank debt more because it is scarce, they are willing to accept an even higher discount on the interest rate on bank debt. This lowers the overall funding costs of bank assets, leading to more - not less - lending in the economy. The idea that the demand for safe and liquid assets drives down yields is at the center of Bernanke (2005) savings glut hypothesis.

The paper proceeds as follows: Section 2 presents a two-sector business cycle model in which households have a preference for safe and liquid assets and banks benefit from government subsidies. Section 3 describes the mechanism and the trade-off of higher capital requirements in the steady-state. Section 4 explains how I take the model to the data and demonstrates how well the model captures moments that have not been targeted. Section 5 discusses the welfare implications.

\section{Model}

I first describe the model. Then I discuss my assumptions in section 2.6. The model incorporates a banking sector into a business cycle model with capital accumulation where

\footnotetext{
${ }^{8}$ For example, Goodhart, Vardoulakis, Kashyap, and Tsomocos (2012) assess different regulatory tools in rich illustrative model.

${ }^{9}$ De Nicolò et al. (2014) find (table 5) that an unregulated bank increases its loan holdings when a small capital requirement is imposed but reduces its size of the loan book when the capital requirement is increased.
} 
the consumption good is produced in two sectors. For one of these sectors, banks operate a production technology and determine its risk. The debt of the banking sector is valued by households as being safe and liquid. Banks receive a subsidy that depends positively on leverage, risk taking, and bank size. The following sections contain a description of the model.

\subsection{Technology}

Consider a single-good economy that produces good $c$ in two different sectors. These two sectors are a bank-independent sector (sector $f$ ) and a bank-dependent sector (sector $h$ ). The firms in the bank-independent sector rent labor and capital from household to form output with a Cobb-Douglas technology

$$
y_{t}^{f}=Z_{t}^{f}\left(k_{t-1}^{f}\right)^{\alpha}\left(N_{t}^{f}\right)^{1-\alpha}
$$

where $Z_{t}^{f}$ is the productivity level at time $\mathrm{t}, k_{t-1}^{f}$ is the capital stock installed in $t-1, \alpha$ is the share of capital, and $N_{t}^{f}$ is the quantity of labor input. Productivity is stochastic

$$
\log Z_{t}^{f}=\rho^{f} \log Z_{t-1}^{f}+\sigma^{f} \epsilon_{t}^{f}
$$

where $\epsilon_{t}^{f}$ is drawn from a multivariate normal distribution.

The bank-dependent production sector is owned and run by banks. Using capital $k_{t-1}^{h}$, they produce output $y_{t}^{h}$ with a decreasing returns to scale technology

$$
y_{t}^{h}=Z_{t}^{h}\left(k_{t-1}^{h}\right)^{v} .
$$

The productivity level $Z_{t}^{h}$ follows

$$
\log Z_{t}^{h}=\rho^{h} \log Z_{t-1}^{h}+\left(\phi_{1}-\phi_{2} \sigma_{t-1}^{h}\right) \sigma_{t-1}^{h}+\sigma_{t-1}^{h} \epsilon_{t}^{h}
$$

where $\epsilon_{t}^{h}$ is drawn jointly with $\epsilon_{t}^{f}$ from $\sim \mathcal{N}\left(\left[\begin{array}{l}0 \\ 0\end{array}\right],\left[\begin{array}{cc}1 & \sigma^{f h} \\ \sigma^{f h} & 1\end{array}\right]\right)$, where $\sigma^{f h}$ is the covariance between $\epsilon_{t}^{f}$ and $\epsilon_{t}^{h}$.

The process of $\log Z_{t}^{h}$ is persistent: Its autocorrelation is $\rho^{h}$. The term $\left(\phi_{1}-\phi_{2} \sigma_{t-1}^{h}\right) \sigma_{t-1}^{h}$ affects the conditional mean. In period $t$, banks choose the amount of risk $\sigma_{t}^{h}$ (i.e. exposure to the aggregate shock $\epsilon_{t}^{h}$ ) at which they want to operate in $t+1$. The choice of $\sigma_{t}^{h}$ also determines the expected productivity level in $t+1$. The parameters $\phi_{1}$ and $\phi_{2}$ govern the shape of the risk-productivity frontier. 


\section{Capital Accumulation}

There is a common capital market for both capital types. Capital in sector $j \in\{f, h\}$ depreciates at the rate $\delta^{j}$ and accumulates according to

$$
k_{t}^{j}=i_{t}^{j}+\left(1-\delta^{j}\right) k_{t-1}^{j}
$$

Adjustments to the stock of capital are costly. When investment exceeds the replacement of depreciated capital, investors incur a proportional capital adjustment cost of

$$
\varphi_{j}\left(\frac{i_{t}^{j}}{k_{t}^{j}}-\delta^{j}\right)^{2} k_{t}^{j}
$$

where $\varphi_{j}$ is the sector-specific adjustment cost parameter.

\subsection{Banking Sector}

Banks make up the financial system in this economy. ${ }^{10}$ They play two roles: First, they produce a good that households consume. Second, their debt is safe and liquid for households who value holding it. Banks are owned by households and maximize shareholder value by generating cash flow that is discounted with households' stochastic discount factor.

Banks enter the period with capital $k_{t-1}^{h}$, government security holdings $b_{t-1}$, bank debt $s_{t-1}$, equity $e_{t-1}$, and a risk level $\sigma_{t-1}^{h}$. The balance sheet equates risky assets $k_{t-1}^{h}$ and riskless assets $b_{t-1}$ to bank debt $s_{t-1}$ and equity $e_{t-1}$ :

$$
k_{t-1}^{h}+b_{t-1}=s_{t-1}+e_{t-1}
$$

At the beginning of the period $t$, the economy's states $\epsilon_{t}^{h}$ and $\epsilon_{t}^{f}$ are realized. Banks generate income from operating their production technology and investing in riskless assets. Their expenses are interest payments on bank debt. Therefore, profits are defined as

$$
\pi_{t}=\underbrace{y_{t}^{h}-\delta^{h} k_{t-1}^{h}}_{\text {production income }}+\underbrace{r_{t-1}^{B} b_{t-1}}_{\text {interest inc. }}-\underbrace{r_{t-1} s_{t-1}}_{\text {interest exp. }} .
$$

In period $t$, banks choose investment $i_{t}^{h}$ as well as risk taking $\sigma_{t}^{h}$ in order to operate the production sector. Additionally, banks have a leverage and a portfolio choice. The leverage

\footnotetext{
${ }^{10}$ Since all banks are identical and the shock to the bank-dependent sector is an aggregate shock, banks' risk choices are perfectly correlated and we can speak of a representative bank that takes prices as given.
} 
choice determines with how much debt $s_{t}$ and with how much equity $e_{t}{ }^{11}$ banks finance their assets. The portfolio choice determines the amount of risky assets $k_{t}^{h}$ and the amount of riskless assets $b_{t}$. Finally, banks decide how much dividends $d_{t}$ to distribute to households.

\section{Market Imperfections in the Banking Sector}

Banks face a regulator who stipulates a constraint on the amount of debt with which banks can finance risky assets:

$$
e_{t} \geq \xi k_{t}^{h}
$$

where $\xi$ determines the amount of equity $e_{t}$ needed to finance risky assets $k_{t}^{h}$. Banks receive a subsidy from the government:

$$
T R\left(k_{t-1}^{h}, \frac{e_{t-1}+\pi_{t}}{k_{t-1}^{h}}, \sigma_{t}^{h}\right)=\omega_{3} k_{t-1}^{h} \exp \left(-\omega_{1}\left(\frac{e_{t-1}+\pi_{t}}{k_{t-1}^{h}}\right)+\omega_{2} \sigma_{t}^{h}\right),
$$

where $\omega_{1}, \omega_{2}$, and $\omega_{3}$ are positive constants. The scalar $\omega_{1}$ is the sensitivity of the transfer with respect to leverage after profits have been realized $\left(k_{t-1}^{h} /\left(e_{t-1}+\pi_{t}\right)\right)$. The scalar $\omega_{2}$ is the sensitivity of the transfer with respect to current risk taking $\sigma_{t}^{h}$, and $\omega_{3}$ determines the average transfer per unit of physical capital. Moreover, since $\sigma_{t}^{h}$ affects the conditional mean of banks' profits in $t+1$, there is an additional benefit of risk taking when banks are highly leveraged.

The adjustment of dividends is costly: Banks incur a cost if their dividend payout deviates from the target level $\bar{d}$. The dividend payout cost introduces intertemporal rigidities into the balance sheet. Following Jermann and Quadrini (2012), the payout cost has the following form:

$$
f\left(d_{t}\right)=\frac{\kappa}{2}\left(d_{t}-\bar{d}\right)^{2}
$$

where $\kappa$ governs the size of this cost.

\section{Problem of Banks}

Banks use equity, profits, and the cash flow from government transfers $T R(\cdot)$ to finance next period's equity $e_{t}$, the capital adjustment costs, and the dividend payout to households. Due to the equity payout costs, the necessary cash flow to payout $d_{t}$ is $d_{t}+f\left(d_{t}\right)$. Therefore,

\footnotetext{
${ }^{11}$ This is the book equity on banks' balance sheet. The book value differs from the market value of equity because banks make profits $\pi_{t}$.
} 
dividends are defined as:

$$
d_{t}=e_{t-1}+\pi_{t}-f\left(d_{t}\right)+T R\left(k_{t-1}^{h}, \frac{e_{t-1}+\pi_{t}}{k_{t-1}^{h}}, \sigma_{t}^{h}\right)-e_{t}-\underbrace{\varphi_{h}\left(\frac{k_{t}^{h}-\left(1-\delta^{h}\right) k_{t-1}^{h}}{k_{t}^{h}}-\delta^{h}\right)^{2} k_{t}^{h}}_{\text {capital adjustment costs }} .
$$

The bank problem is written recursively. For the statement of the problem, it is useful to define $\tilde{e}=e+\pi$ as equity after profits. The state of the economy $\varepsilon$ is determined by the realizations of the shocks $\epsilon^{f}$ and $\epsilon^{h}$. Thus, the state variables of banks are the aggregate state vector $X$ (to be described later), the state of the economy $\varepsilon$, equity after profits $\tilde{e}(\varepsilon, X)$, as well as $k^{h}$ due to the adjustment costs of capital. Banks discount the future with the pricing kernel $M\left(X^{\prime}, \varepsilon^{\prime}\right)$ from households. They choose capital, government securities, bank debt, the amount of risk-taking, equity after profits (and therefore book equity), as well as dividends to solve

$$
V^{B}\left(\tilde{e}, k_{h}, X, \varepsilon\right)=\max _{k^{\prime h}, b^{\prime}, s^{\prime}, \sigma^{\prime h}, \tilde{\mathbf{e}}^{\prime}\left(\varepsilon^{\prime}, X^{\prime}\right), d} d+\mathbf{E}_{\varepsilon^{\prime} \mid \varepsilon}\left[M\left(X^{\prime}, \varepsilon^{\prime}\right) V^{B}\left(\tilde{\mathbf{e}}^{\prime}\left(\varepsilon^{\prime}, X^{\prime}\right), k ;^{h}, X^{\prime}, \varepsilon^{\prime}\right)\right]
$$

subject to

$$
\begin{aligned}
d & =\tilde{e}-e^{\prime}-f(d)+T R\left(k^{h}, \frac{\tilde{e}}{k^{h}}, \sigma^{\prime h}\right)-\varphi_{h}\left(\frac{k^{\prime h}-\left(1-\delta^{h}\right) k^{h}}{k^{\prime h}}-\delta\right)^{2} k^{\prime h} \\
\tilde{\mathbf{e}}^{\prime}\left(\varepsilon^{\prime}, X^{\prime}\right) & =e^{\prime}+\pi\left(k^{\prime h}, \sigma^{\prime h}, b^{\prime}, s^{\prime}, X^{\prime}, \varepsilon^{\prime}\right) \\
k^{\prime h}+b^{\prime} & =e^{\prime}+s^{\prime} \\
e^{\prime} & \geq \xi k^{\prime h} .
\end{aligned}
$$

Banks have unlimited liability: if $\tilde{e}<0$ they set $d<0$.

\subsection{Households}

Households are all identical and live indefinitely. They own capital $k^{f}$ for firm production and supply labor $N^{f}$ to firms inelastically. They are also the owners of banks and as such receive dividends $d$.

Households care about consumption $c$ and holding safe and liquid assets in the form of bank debt $s$. Bank debt gives utility in the period it is acquired and pays interest in the following period. The felicity function is defined over consumption and bank debt $\left(s^{\prime}\right)$ in a 
money-in-the-utility specification

$$
U\left(c, s^{\prime}\right)=\log c+\theta \frac{\frac{s^{\prime} 1-\eta}{c}}{1-\eta}
$$

where $\theta$ is the utility weight on deposits and $\eta$ governs the curvature of the deposit-consumption ratio in the utility. This utility specification ensures that more consumption raises the marginal utility of liquidity. At the beginning of the period after the shocks have been realized (realizations of $\epsilon^{h}$ and $\epsilon^{f}$ are summarized in vector $\varepsilon$ ), the state variable of the household is net worth $n$

$$
n(\varepsilon)=\text { Financial Wealth + Capital -Taxes. }
$$

Financial wealth consists in dividends $d$ and share value $p$ from owning $\Theta$ shares of the banking sector and $s$ bank debt:12

$$
\text { Financial Wealth }=(d(X, \varepsilon)+p(X, \varepsilon)) \Theta+(1+r(X)) s \text {. }
$$

That is, households do not hold bonds. Later, I will verify that in equilibrium they also do not want to hold bonds. Households own capital $k^{f}$ which they rent out to firms

$$
\text { Capital }=\left(r^{f}(X, \varepsilon)+1-\delta\right) k^{f}
$$

Lump sum taxes are denoted as $T$. Additionally, households receive labor income from supplying $N_{k}$ hours inelastically to firms, earning wage $w^{f}$. Thus labor income is

$$
\text { Labor Income }=w^{f}(X, \varepsilon) N^{f} \text {. }
$$

Households' value function is determined by $n, k^{f}$, the aggregate state vector $X$, and the realization of shocks $\varepsilon$. They maximize their value function by choosing consumption $c$, new deposit balance $s^{\prime}$, capital $k^{\prime f}$, labor supply $N^{f}$, and bank shares ${ }^{13} \Theta^{\prime}$ subject to a budget constraint. Thus, their problem is to solve

$V^{H}\left(n, k_{k}, X, \varepsilon\right)=\max _{\left\{c, s^{\prime}, k^{\prime}, N^{f}, \Theta^{\prime}, n^{\prime}\left(X^{\prime}, \varepsilon^{\prime}\right)\right\}} U\left(c, s^{\prime}\right)+E_{\varepsilon^{\prime} \mid \varepsilon}\left[M\left(X^{\prime}, \varepsilon^{\prime}\right) V^{H}\left(n^{\prime}\left(X^{\prime}, \varepsilon^{\prime}\right), k^{\prime f}, X^{\prime}, \varepsilon^{\prime}\right)\right]$

\footnotetext{
${ }^{12}$ The model captures the effects of government guarantees though the government guarantee itself is not formally in the model. A consequence of a government guarantee is that depositors regard bank debt as perfectly riskless.

${ }^{13}$ Households own the banking sector which means that they hold $\Theta$ shares of the claim on banks' dividends and the market value.
} 
subject to the budget constraint

$$
c+s^{\prime}+(1+\underbrace{\varphi_{f}\left(\frac{k^{\prime f}-\left(1-\delta^{f}\right) k^{f}}{k^{\prime f}}-\delta\right)^{2}}_{\text {capital adjustment costs }}) k^{\prime f}+p(X, \varepsilon) \Theta^{\prime}=n(\varepsilon)+w^{f}(X, \varepsilon) N^{f},
$$

and net worth tomorrow

$$
n^{\prime}\left(X^{\prime}, \varepsilon^{\prime}\right)=\left(d\left(X^{\prime}, \varepsilon^{\prime}\right)+p\left(X^{\prime}, \varepsilon^{\prime}\right)\right) \Theta^{\prime}+\left(1+r\left(X^{\prime}\right)\right) s^{\prime}+\left(r^{f}\left(X^{\prime}, \varepsilon^{\prime}\right)+1-\delta^{f}\right) k^{\prime f} .
$$

When installing new capital in excess of depreciation, the household incurs the cost $\varphi_{f}\left(\left(k^{\prime f}-\left(1-\delta^{f}\right) k^{f}\right) / k^{\prime f}-\delta^{f}\right)^{2}$ per unit of capital $k^{\prime f}$. The stochastic discount factor in the economy is given by

$$
M\left(X^{\prime}, \varepsilon^{\prime} \mid \varepsilon\right)=\beta\left(\frac{U_{c}\left(c\left(X^{\prime}, \varepsilon^{\prime}\right), s^{\prime}\right)}{\left.U_{c}(c(X, \varepsilon), s)\right)}\right) .
$$

\subsection{Government}

The government follows a balanced budget rule where it maintains debt levels at $B^{\prime}=B$ so that:

$$
T R(\cdot)+r^{B} B=T .
$$

\subsection{Recursive Competitive Equilibrium}

The timing in the model is as follows: shocks occur and decisions are made subsequently. Then a new period starts again. The state vector $X$ contains the aggregate net worth of banks $\tilde{E}$, the aggregate net worth of households $N$, the aggregate capital stock of households $K^{f}$, the aggregate capital stock of banks $K^{h}$, and the productivity levels of firms and banks $Z^{f}$ and $Z^{h}$ respectively.

Definition. Given an exogenous ${ }^{14}$ government debt policy $B$, a recursive competitive equilibrium is defined by a pricing kernel $M(X, \varepsilon)$ and prices: $w^{f}(X, \varepsilon), r^{f}(X, \varepsilon), r^{h}(X, \varepsilon)$, $p(X, \varepsilon), r(X)$, and $r^{B}(X)$, value functions for households $V^{H}$ and banks $V^{B}$, and policy functions of households for consumption $P_{H}^{c}$, bank debt $P_{H}^{s^{\prime}}$, capital $P_{H}^{k^{\prime f}}$, bank equity shares $P_{H}^{\Theta^{\prime}}$, labor supply $P_{H}^{N^{f}}$, as well as policy functions of banks for their capital stock $P_{B}^{k^{\prime h}}$, bonds

\footnotetext{
${ }^{14}$ Government securities are not a choice variable in this model because otherwise the government could optimally set $B=\infty$, financed with non distortionary taxes. It would be optimal to do so, because households receive utility from deposits which can be produced with government debt.
} 
$P_{B}^{b^{\prime}}$, bank debt $P_{B}^{s^{\prime}}$, equity $P_{B}^{e^{\prime}}$, dividends $P_{B}^{d}$, and $P_{B}^{\sigma^{\prime h}}$, and $\mathcal{H}$ the function governing the law of motion for $X$ such that

1. Given the price system and a law of motion for $X$ :

(a) the policy function $P_{B}^{k^{\prime h}}, P_{B}^{b^{\prime}}, P_{B}^{s^{\prime}}, P_{B}^{e^{\prime}}, P_{B}^{d}, P_{B}^{\sigma^{\prime h}}$, and the value function for banks $V^{B}$ solve the Bellman equation, defined in equation 6 .

(b) the policy function $P_{H}^{c}, P_{H}^{s^{\prime}}, P_{H}^{k^{\prime}}, P_{H}^{\Theta^{\prime}}, P_{H}^{N^{f}}$, and the value function for households $V^{H}$ solve the Bellman equation, defined in equation 8.

2. $w^{f}(X, \varepsilon)$ and $r^{f}(X, \varepsilon)$ satisfy the optimality conditions of firms.

3. For all realization of shocks, the policy functions imply

(a) market clearing for

i. government bonds: $P_{B}^{b^{\prime}}=B$

ii. bank debt: $P_{B}^{s^{\prime}}=P_{H}^{s^{\prime}}$

iii. capital: $P_{H}^{k^{\prime f}}+P_{B}^{k^{\prime h}}=k^{\prime f}+k^{\prime h}$

iv. labor $P_{H}^{N^{f}}=N^{f}$

v. bank shares: $\Theta=1$

vi. consumption:

$$
\begin{aligned}
c= & y^{h}+y^{f}+\left(1-\delta^{f}\right) k^{f}+\left(1-\delta^{h}\right) k^{h}-\frac{\kappa}{2}(d-\bar{d})^{2} \\
& -k^{\prime f}\left(1+\varphi_{f}\left(\frac{i^{\prime f}}{k^{\prime f}}-\delta^{f}\right)^{2}\right)-k^{\prime h}\left(1+\varphi_{h}\left(\frac{i^{\prime h}}{k^{\prime h}}-\delta^{h}\right)^{2}\right)
\end{aligned}
$$

(b) consistency with aggregation: $n=N, \tilde{e}=\tilde{E}, k^{f}=K^{f}$ and $k^{h}=K^{h}$.

4. The government budget constraint in equation 11 is satisfied.

5. The law of motion for $X$ is consistent with the policy functions, rational expectations, and $X^{\prime}=\mathcal{H}(X)$.

The full set of equilibrium equations is listed in the web appendix section A. 


\subsection{Discussions of Assumptions}

This section discusses the important assumptions of the model.

\section{Household's Demand for Safe and Liquid Assets}

Diamond and Dybvig (1983) ${ }^{15}$ were the first who explicitly analyzed the idea of households' liquidity demand and the role of banks as liquidity providers. In this model, households value bank debt because it is liquid and safe. The idea to interpret bank debt as such goes back to Gorton and Pennacchi (1990) and is also present in Gorton et al. (2012). ${ }^{16}$ The recent crisis has inspired researchers to investigate more generally the demand for safe and liquid assets, for example Bernanke (2005), Gourinchas and Jeanne (2012), and Krishnamurthy and Vissing-Jorgensen (2012).

I capture the demand for safe and liquid assets in the form of bank debt similar to a money-in-the-utility function specification. Due to households' demand for bank debt, it is optimal for banks to be highly leveraged aside of government subsidies. DeAngelo and Stulz (2013) show this mechanism in a stylized model.

Since Sidrauski (1967) money-in-the-utility specifications have been used to capture the benefits from money-like-securities for households in macroeconomic models. ${ }^{17}$ Feenstra (1986) showed the functional equivalence of models with money-in-the-utility and models with transaction or liquidity costs. The specific form of the utility function in this paper reflects that more consumption raises the marginal utility of bank debt holdings for households and is a version of Poterba and Rotemberg (1986) and Christiano, Motto, and Rostagno $(2010) .^{18}$

\section{Bank-Owned Production Sector}

The final good is produced by two production sectors: bank-dependent and non-bankdependent. This assumption assigns banks an important role in the provision of a good that households value. The idea that some agents need lenders (banks) to realize production projects underlies Bernanke and Gertler (1989) as well as Kiyotaki and Moore (1997). This

\footnotetext{
${ }^{15}$ Other papers have built upon this idea, see Diamond and Rajan (2000), Gorton and Pennacchi (1990), and Holmström and Tirole (2011).

${ }^{16}$ Their definition of safe assets includes basically any liabilities that banks hold: bank deposits, money market fund shares, commercial paper, repos, short-term interbank loans, Treasuries, agency and municipal debt, securitized debt, and high-grade financial sector corporate debt.

${ }^{17}$ There are other ways of eliciting liquidity demand of households. For instance, Chari, Christiano, and Eichenbaum (1995) use a shopping time technology in which deposits help to reduce the time spent on purchasing good. Schneider and Doepke (2013) rationalize the existence of money through its use as a dominant unit of account.

${ }^{18}$ Their money and deposit utility parameter relates to the bank debt-consumption elasticity $\eta$ in the following way: $\sigma_{q}=2-\eta$.
} 
assumption makes a part of production dependent on the ability to obtain funds from lenders.

The bank-dependence of one production sector reflects the fact that banks generally provide funds to borrowers who do not have access to capital from elsewhere due to informational asymmetries. Those borrowers are usually small businesses and households who want to buy property. To fix ideas, the bank dependent production sector can be thought of the construction sector that depends on households' access to mortgages. In the literature (e.g. Freixas and Rochet (1998)), banks emerge as a solution to the asymmetric information problem between borrowers and lenders by gathering information (for instance through long term relationships as in Sharpe (1990)) and by screening and monitoring (as emphasized by Diamond (1984) and Tirole and Holmstrom (1997)). These practices allow banks to choose the riskiness and investment scale of their borrowers.

The present model goes a step further: banks own the capital stock used in the bank dependent sector and operate the production technology. This idea has been used by Brunnermeier and Sannikov (2012). ${ }^{19}$ By allowing banks to own a production sector, I can study the behavior of banks in a tractable set-up. This abstraction serves the purpose to focus on the market imperfections that matter most for banks' investment, leverage, and risk choices.

\section{Decreasing Returns to Scale in Bank Dependent Sector}

The bank dependent sector operates a decreasing returns to scale technology in capital. This captures the idea that not all projects in the world are suitable to be carried out by the banking sector. In other words, it is a stand-in for the degree to which banks can profitably eliminate the asymmetric information between them and their borrowers. This assumption also allows me to analyze the size of the banking sector in a meaningful way.

More specifically, this assumption captures the following idea: banks can profitably lend to bank dependent borrowers because their monitoring and long term relationship building mitigates the asymmetric information problems that hinder these borrowers to access capital markets. These borrowers, however, are not homogeneous: There are top borrowers that are very productive with low default risk and other borrowers that are not. Also, monitoring is costly. It is only profitable for banks to lend to borrowers as long as the benefit of lending matches or exceeds its costs. This is particularly true for capital intensive projects where it is easier to monitor the investment process. When banks start lending to the bank-dependent sector they first lend to the profitable borrowers which makes these investments attractive. After that there are only less profitable investments left because the remaining borrower pool requires more monitoring, defaults more, or is less productive.

\footnotetext{
${ }^{19}$ It can be shown that this set up is isomorphic to a model in which bank borrowers have zero net worth and banks own a monitoring technology that allows them to effectively eliminate the asymmetric information.
} 


\section{Bank's Risk and Return Menu}

The stochastic productivity term, described in equation (4), depends on banks' risk choice $\sigma^{h}$. This choice is equivalent to picking a project from a risk-return menu (i.e. the particular combination of mean and risk exposure). This specification postulates a trade-off between mean and exposure. The menu of projects $Z^{h}$ is set to have an interior maximum in $\sigma^{h}$. As a consequence, there exists a $\sigma^{h}$ that is optimal in the sense of maximizing mean productivity $Z^{h} .^{20}$

The concavity of $Z^{h}$ is meant to capture a decline in returns for high amounts of risk. Generally, when investing in the stock market, mean returns can be increased with higher risk. ${ }^{21}$ Regulators want to minimize the amount of systematic risk taken by banks and therefore limit their ability to invest in high risk/ high return projects. ${ }^{22}$ If banks nevertheless want to increase their systematic risk exposure, they have to do this in ways that escape regulators. These evasive investment strategies can compromise mean returns since they involve the inefficient use of resources to avoid regulatory scrutiny.

\section{Adjustment Costs to the Banking Capital Stock}

Bank borrowers choose banks because they find it more difficult to obtain funds elsewhere. Banks build relationships with their customers to overcome the asymmetric information as, for instance, described by Sharpe (1990). It is costly to build up these costumer relationships. A sudden reduction in the loan portfolio may also be costly because other market participants lack the information that the selling bank has acquired over time.

\section{Dividend Adjustment Costs}

Corporations, including banks, smooth dividends. Lintner (1956) showed that managers smooth dividends over time. In the case of banks, Dickens, Casey, and Newman (2002) used Morningsart's Stocktools/Prinicpia Pro data from 1998-2000 to show that past dividends strongly predict future dividends of banks.

As in Jermann and Quadrini (2012), I capture the smoothness of dividends through a quadratic dividend adjustment costs function. Costs arise when the payout deviates from

\footnotetext{
${ }^{20}$ Marshall and Prescott (2006) have a model that generates a reverse mean-variance trade-off for banks' investment choices

${ }^{21}$ Banks have incentives to take on systematic risk (i.e. exposure to $\epsilon^{h}$ ) because it increases their chances of being saved by the government.

${ }^{22}$ They assess how diversified banks are and subject them to a more stringent capital requirement if they are insufficiently diversified. Also, regulators discourage banks from investing into the stock market.
} 
the steady state target level:

$$
f(d)=\frac{\kappa}{2}(d-\bar{d})^{2}
$$

In this model, dividend adjustment costs introduce intertemporal rigidities into the balance sheet, which make banks' choices of equity dependent on the current level of equity. This is consistent with the observation of Adrian and Shin (2011), who found that bank equity is sticky. The stickiness of equity can be derived from debt overhang problems (see discussion in Admati and Hellwig (2013)) and equity issuance costs. Paying out too much dividends can also be costly because of an increasing marginal tax rate on equity distributions (see Hennessy and Whited (2007)).

\section{The Subsidy Function}

In the model, the banking sector receives a subsidy from the government. These payments are increasing in (i) size, (ii) leverage, and (iii) risk taking of banks. I parametrize the subsidy function in the following way:

$$
T R\left(k^{h}, \frac{\tilde{e}}{k^{h}}, \sigma^{\prime h}\right)=\omega_{3} k^{h} \exp \left(-\omega_{1} \frac{\tilde{e}}{k^{h}}+\omega_{2} \sigma^{\prime h}\right),
$$

where $k^{h}$ are the risky assets that banks hold, $\tilde{e}=e+\pi$ represents equity after profits, and $\sigma^{\prime h}$ denotes the risk choice of banks for the next period.

In the data, banks have limited liability and are beneficiaries of explicit (FDIC insurance) or implicit government guarantees (i.e. bailout). Without government protection, the risk of default is reflected in the cost of borrowing. If instead governments act as backstops to banks, ${ }^{23}$ debt holders do not require compensation for default risk. This lowers the cost of debt financing and helps explain high leverage ratios of banks in the data.

In the model, banks have unlimited liability but receive a subsidy that depends on leverage and risk taking. The subsidy in the form of the transfer function captures the effects of a banking system that is considered too-big-to-fail. This has two consequences. First, default does not occur in equilibrium. Second, government guarantees act effectively as subsidies by lowering the debt financing costs for banks because default risks are not priced into the claims that banks issue. The value of government guarantees is reflected in the transfer function's positive dependence on leverage, risk-taking, as well as the size of the bank. Moreover, it captures the value of tax rules that benefit debt over equity financing. One of the first papers to model the effect of bailout guarantees over the business cycle is by Schneider and Tornell (2004). Government subsidies are also the core friction in Admati

\footnotetext{
${ }^{23}$ Deposit insurance by the FDIC is a particular feature of commercial banks. If deposit insurance is mispriced, it distorts banks' debt financing costs similar to implicit government guarantees
} 
et al. (2012).

Bank owners may have incentives to take on excessive risks when they have limited liability. In fact, equity claims are call-options on bank assets, an analogy that was first discussed by Black and Scholes (1973). More risk increases the value of the call option. Gollier, Koehl, and Rochet (1997) show that the risk exposure of firms with limited liability is always larger than that of firms with unlimited liability. Pennacchi (2006) presents a model in which deposit insurance subsidizes banks and that banks can increase the subsidy by concentrating their loan portfolio in systematic risk. Begenau, Piazzesi, and Schneider (2013) demonstrate empirically that commercial banks' uses of derivatives increase the risk exposure of banks' balance sheet instead of hedging that exposure.

In the present model, risk-taking incentives are captured through the subsidy's dependence on $\sigma^{h}$ and through the functional form of the transfers which captures complementarity between risk taking and leverage. That is, risk taking incentives are particularly strong when banks are highly leveraged. The transfer is increasing in $\sigma^{\prime h}$ because banks effectively save the risk premium which they would need to pay without a guarantee.

There is a subsidy on debt for all firms in the US. But the tax-advantage matters particularly for the financial sector because they compete on small interest margins (e.g. Hanson, Stein, and Kashyap (2010)). The scalar $\omega_{3}$ in the transfer function captures the tax-advantage per dollar of debt.

The internet appendix demonstrates how a model with an explicit default choice by banks and government bailout implies a bailout payoff function that resembles the reduced form subsidy function considered here.

\section{Bank Capital Requirements}

Banks are subject to a Basel-II type of capital requirement. The Basel-II accords stipulate that banks must hold a certain percentage of risk-weighted assets in terms of equity. Under these rules, assets that are considered safe such as government securities receive a $0 \%$ risk weight. In the model banks have to hold $\xi$ dollars of equity $e$ for each dollar of risky assets $k^{h}$.

\section{Mechanism and Trade-off}

This section illustrates the mechanism that works against the standard intuition of how higher capital requirements affect bank lending in a simplified social planner world. Households' preferences for bank debt lower the equilibrium interest rate on bank debt. This implies that banks' capital constraint is binding even without government subsidies. Subsec- 
tion 3.2 describes the trade-offs of higher capital requirements in the non-stochastic steady state.

\subsection{Mechanism in the Social Planner World}

Consider a simplified version of the previously described model. The technology is described by equations 1-4 and the standard accumulation of capital without adjustment costs. Preferences are as described in 7 . The social planner chooses the optimal amount of the capital stock in both sectors and consumption to maximize the present value of households' lifetime utility, taking into account the resource constraint and the fact that bank debt must be produced with $k^{h}$. The problem is:

$$
\begin{aligned}
& V^{F B}(X, \varepsilon)=\max _{k^{\prime h}, k^{\prime f}, c} \log c+\theta \frac{\left(\frac{k^{\prime h}}{c}\right)^{1-\eta}}{1-\eta}+E_{\varepsilon^{\prime} \mid \varepsilon}\left[M\left(X^{\prime}, \varepsilon^{\prime} \mid \varepsilon\right) V^{F B}\left(X^{\prime}, \varepsilon^{\prime}\right)\right], \\
& \text { s.t. } \\
& c+k^{\prime f}+k^{\prime h}=y^{f}+y^{h}+(1-\delta)\left(k^{h}+k^{f}\right),
\end{aligned}
$$

using $s=k^{h}$. The state vector $X$ contains the aggregate capital stock $k=k^{h}+k^{f}$, and the productivity levels $Z^{h}$ and $Z^{k}$. In non-stochastic steady state, the first order conditions are

$$
\begin{aligned}
\frac{c}{k} & =\frac{y}{k}+(1-\delta) \\
\frac{\partial y^{f}}{\partial k^{f}}-\delta & =\frac{1}{\beta}-1 \\
\frac{\partial y^{h}}{\partial k^{h}}-\delta & =\frac{1}{\beta}-1-\frac{1}{\beta} \frac{\theta\left(\frac{k^{h}}{c}\right)^{-\eta}}{1-\theta\left(\frac{k^{h}}{c}\right)^{1-\eta}},
\end{aligned}
$$

where $y=y^{h}+y^{f}$. The last term in (14) is the marginal rate of substitution between bank debt and consumption. Equations (13) and (14) demonstrate that the marginal product of capital in the firm sector is higher than the marginal product in the bank dependent sector. The latter displays a higher capital-output ratio in order to satisfy the demand for safe and liquid assets. The marginal product of capital across these two production sectors does not equalize because capital in the banking sector produces liquidity and a part of the final 
good. ${ }^{24}$ The optimal amount of $k_{h}$ is the solution to these equations:

$$
\begin{aligned}
c & =y+(1-\delta)\left(k^{f}+k^{h}\right) \\
\frac{\partial y^{h}}{\partial k^{h}}+\frac{1}{\beta} \frac{\theta\left(\frac{k_{h}}{c}\right)^{-\eta}}{1-\theta\left(\frac{k_{h}}{c}\right)^{1-\eta}}-\delta & =\frac{1}{\beta}-1 .
\end{aligned}
$$

The right hand side of equation 16 describes the opportunity cost of investing one unit of the final good in the bank dependent sector instead of in the non-banking sector and the left hand side describes its benefit. Figure (3) illustrates the equilibrium in the first best. It plots equation (16)'s left hand side as a dashed line and the ride hand side as a solid line. The optimal amount of $k^{* h}$ is found at the intersection of the dashed and solid line. Without the liquidity (or bank deposit) premium, the equilibrium would be found outside to the left on this picture where the marginal product of $k^{h}$ (dot-dash line in figure (3)) equates the marginal product of $k^{f}$. The liquidity premium introduces a wedge between the marginal products of capital in the two sectors, leading to a higher equilibrium level of $k^{h}$. Any $k^{h}>k^{* h}$ implies too much investment into the banking sector. Any $k^{h}<k^{* h}$ implies too little investment into the banking sector, not satisfying households' liquidity demand. The optimal amount of the bank-dependent capital stock depends on the utility parameters of households.

\section{Imposing a Capital Requirement}

In order to illustrate the mechanism, I analyze what happens when the social planner makes her choice under the restriction that the bank dependent sector faces a capital requirement. This changes the amount of bank produced to $s=(1-\xi) k^{h}$. Substituting this expression into the objective of problem 12 the first order conditions change to:

$$
\frac{\partial y^{h}}{\partial k^{h}}+\frac{1}{\beta} \frac{\theta(1-\xi)^{1-\eta}\left(\frac{k^{h}}{c}\right)^{-\eta}}{1-\theta(1-\xi)^{1-\eta}\left(\frac{k^{h}}{c}\right)^{1-\eta}}-\delta=\frac{1}{\beta}-1
$$

That is, the marginal rate of substitution between consumption and bank debt depends on $\eta$. In the first best, welfare is always maximized by choosing a capital requirement of $\xi=0$ since any $\xi>0$ reduces the amount of bank debt.

The question is how does the capital stock in the economy with $\xi>0$ compare to the first best? The answer to this question provides the intuition for the effect of the capital

\footnotetext{
${ }^{24}$ With preference for liquidity, the capital stock is thus higher than the modified golden rule level (also discussed in Van Den Heuvel (2008)).
} 
requirement on bank lending in the full model. Parameter $\eta$ (an elasticity) governs how the demand for safe and liquid assets $s$ relative to consumption (marginal rate of substitution (MRS)) depends on its amount and therefore, on the capital requirement. When the demand bank debt is not too elastic $(\eta>1)$, equation 17 implies that the social planner chooses more $k^{h}$ compared to the first best to prevent bank debt holdings from falling too much. In this case the MRS is increasing in $\xi$. In contrast when $\eta<1$, the social planner chooses a smaller level of $k^{h}$ compared to the first best because utility can be increased by substituting consumption for bank debt (MRS is decreasing in $\xi$ ). When $\eta=1$ the income and substitution effect cancel. The term $(1-\xi)$ drops out of the utility and we are back to the first best. ${ }^{25}$

\subsection{Trade-Off}

I characterize the trade-off that occurs when the capital requirement is increased. The nonstochastic steady state equilibrium is the equilibrium in which $Z^{h}$ and $Z^{f}$ are constants.

Definition. Given an exogenous government debt policy $B$, a steady state equilibrium is defined by a constant level of $Z^{h}$ and $Z^{f}$, a pricing kernel $M(X)$ and prices: $w^{f}(X)$, $r^{f}(X), r^{h}(X), p(X), r(X)$, and $r^{B}(X)$, value functions for households $V^{H}$ and banks $V^{B}$, and policy functions of households for consumption $P_{H}^{c}$, bank debt $P_{H}^{s^{\prime}}$, capital $P_{H}^{k^{\prime f}}$, bank equity shares $P_{H}^{\Theta^{\prime}}$, labor supply $P_{H}^{N^{f}}$, as well as policy functions of banks for their capital stock $P_{B}^{k^{\prime h}}$, bonds $P_{B}^{b^{\prime}}$, bank debt $P_{B}^{s^{\prime}}$, equity $P_{B}^{e^{\prime}}$, dividends $P_{B}^{d}$, and $P_{B}^{\sigma^{\prime h}}$ and a law of motion for $X$ such that the equilibrium definition in section 2.5 is satisfied.

\section{Interest Rate Discount on Bank Debt}

Households value bank debt because it is safe and liquid. This implies a discount on its interest rate. The discount is the amount households are willing to give up in exchange for holding bank debt compared to another riskless asset. It equals the marginal increase in utility from increasing the holdings of bank debt by one dollar keeping the marginal utility of consumption constant. The first order condition of households with respect to bank debt holdings in the non-stochastic steady state is:

$$
\frac{\partial U(c, s)}{\partial s} \times\left(1 / \frac{\partial U(c, s)}{\partial c}\right)=\left(\frac{r^{e}-r}{1+r^{e}}\right)
$$

where $1 / M(X) \equiv 1+r^{e}$ and $\partial U(c, s) / \partial s^{\prime}=\theta s^{-\eta} c^{\eta-1}$ is the marginal utility of bank debt

\footnotetext{
${ }^{25}$ The $\eta$ ranges that determine banks' physical capital stock $k^{h}$ response to an increase in the capital requirement depends on the amount of government debt $B$. In the example shown here, $B=0$ and banks' capital stock remains unchanged whenever $\eta=1$. When $B$ is set to its average value on banks' balance sheet, the value of $\eta$ that makes $k^{h}$ independent of changes in the capital requirement is 1.39.
} 
holdings and $\partial U(c, s) / \partial c=1 / c-\theta s^{1-\eta} c^{\eta-2}$ is the marginal utility of consumption, which are both positive. The left hand side of equation (18) is the marginal rate of substitution between bank debt and consumption. The right hand side is the spread between equity and bank debt financing in the steady state which is positive as long as households are not saturated with liquidity.

As discussed in section 3.1, the left hand side of equation (18) depends on the amount of safe and liquid assets $s$. When $\eta>1$, a reduction in $s$ makes safe and liquid assets more valuable to households, which is expressed by an increased marginal utility of $s$ relative to consumption. Higher demand drives down the yield on bank debt as in Bernanke (2005) savings glut hypothesis. That is, the MRS in the left hand side of equation (18) increases, leading to an increase in the interest rate discount (the $\operatorname{spread}^{26}$ between $r^{e}$ and $r$ ) and therefore a reduction in the interest rate on bank debt $r .{ }^{27}$

\section{Banks' Capital Constraint}

In the non-stochastic steady state and for every combination of parameters, the capital constraint of banks is binding if either households have preference for bank debt or banks receive transfers from the government that imply a debt benefit. This is expressed in the first order condition of banks with respect to equity in the non-stochastic steady state:

$$
\mu=\frac{r^{e}-r}{1+r^{e}}+\omega_{1} T R\left(1, \frac{\tilde{e}}{k^{h}}, \sigma^{h}\right)\left(\frac{1+r}{1+r^{e}}\right)
$$

where $\mu$ is the Lagrange multiplier on the capital constraint in (6). The multiplier tells us that increasing equity by one unit relaxes the capital constraint by $\mu$. The right hand side of equation (19) reflects the opportunity costs of doing. Banks give up the interest rate discount on debt and they lower the subsidy due to a reduction in leverage. The capital constraint is binding for any parametrization because financing with debt is cheaper than with equity: one dollar of debt raised today results in a positive net profit $r^{e}-r>0$ tomorrow. $^{28}$

\footnotetext{
${ }^{26}$ In the steady state $r^{e}=r^{f}-\delta$ (the interest rate on capital employed in the non-bank dependent sector) because households first order condition with respect to capital $k^{f}$ in the steady state is $1 / M=\left(1+r^{f}-\delta\right)$. This means that bank equity holders must be paid the same return as they would obtain from investing one dollar into the firm sector and receiving the return $\left(1+r^{f}-\delta\right)$.

${ }^{27}$ In the households' problem, households were not given the option to invest in government bonds. In fact, households do not want to hold government bonds because they have the same risk characteristics as bank liabilities without providing utility. Moreover, government bonds earn the same interest rate because government bonds are risk free and receive a risk weight of zero in the capital constraints of banks $(e \geq$ $\left.\xi k^{h}+0 \times b\right)$. If returns were not equated, there would be an arbitrage opportunity: banks could issue more debt to buy bonds driving down the interest rate. Or if bonds are more expensive than bank debt (low interest rate), banks would not want to hold bonds.

${ }^{28}$ The government subsidy is an additional reason for a binding capital constraint. Without households' preference for liquidity or a subsidy for banks, the rate on bank debt equals the interest rate on capital
} 


\section{Optimal Size of the Banking Sector}

Decreasing returns to scale in the bank dependent production technology implies an optimal size of the banking sector. It is determined by banks' first order condition of equity (see equation (19)) and risky assets:

$$
\underbrace{\frac{T R}{k^{h}}\left(1+\omega_{1}(1-v) \frac{y^{h}}{k^{h}}\right)}_{:=\frac{\partial T R}{\partial k^{h}}>0}+\left(1+r^{h}-\delta^{h}\right)=\xi\left(1+r^{e}\right)+(1-\xi)(1+r),
$$

where $r^{h} \equiv v y^{h} / k^{h}$. Given the interest rates on debt and equity, the optimal size of the banking sector trades off the benefits (left hand side) and costs of risky assets (right hand side of equation (20)). This equation tells us what an additional unit of capital is worth, keeping leverage constant. The marginal benefit of capital equals the $r^{h}$ and the marginal subsidy $\partial T R / \partial k^{h}$. The funding cost of $k^{h}$ (right hand side) is a weighted average between two interest rates: $1+r^{e}$ is the interest rate that needs to be paid to the shareholder and $1+r$ is the interest rate that needs to be paid to debt holders. The subsidy drives a wedge between the funding costs and the return on risky assets. Given a level of funding costs, the higher the value of the subsidy the lower the marginal product of risky assets. This implies that banks are larger in a world with subsidies than in a world without subsidies, consistent with the finding of Gandhi and Lustig (2010).

\section{Risk-Taking Incentives}

The risk-return trade-off embedded in the technology of banks allows me to infer banks' risk choice also in the steady state: the variable $\sigma^{h}$ determines not only the exposure to the aggregate shock (which is not defined in the non-stochastic steady state) but also the mean productivity in banks' technology and the flow payment from the government subsidy which are both defined in the steady state. The first order condition of banks with respect to the amount of the risk-taking variable $\sigma^{h}$ yields the optimal risk choice:

$$
\sigma^{h}=\underbrace{\frac{\phi_{1}}{2 \phi_{2}}}_{\max Z^{h}}+\underbrace{\frac{\left(1+r^{e}\right)}{2 \phi_{2}} \frac{k^{h}}{y^{h}} \frac{\omega_{2} T R / k^{h}}{1-\omega_{1} T R / k^{h}}}_{\text {Subsidy }} .
$$

Without the transfer, the optimal risk choice is equal to the first term of equation (21) that maximizes the productivity level of the production technology of banks in the steady state.

(Friedman rule) in the non-stochastic steady state, $r=r^{e}$. In this case (and without the subsidy), the capital requirement would have no effect on the equilibrium. 
When banks receive a subsidy which is sensitive to risk taking $\left(\omega_{2}>0\right)$ banks take on more risk than the amount that maximizes the productivity of banks' technology. The scalar $\omega_{2}$ governs how much more risk banks want to choose over the level that maximizes productivity.

\section{Effect of an Increase in the Capital Requirement}

Banks can respond in three ways to comply with a higher requirement. They can increase equity holding assets constant. They can decrease assets holding equity constant. Or they can increase equity and assets which may or may not hold bank debt constant.

Holding interest rates constant, a higher capital requirement increases the funding costs of risky assets in equation (20) because a larger share of assets has to be financed with relatively more expensive equity. Indeed, this is a familiar result from partial equilibrium models. The decreasing returns to risky assets in the bank dependent production technology implies that a reduction in risky assets leads to a higher return. Thus to increase the return on assets to match higher funding costs, banks achieve the reduction in leverage through a reduction in assets and, consequently, bank debt.

In general equilibrium, however, the interest rates on bank debt change with an increase in the capital requirement, affecting banks' funding costs. As argued above, equation (18) determines the response of banks' debt financing costs to a change in the amount of bank debt. In case households value safe and liquid assets more the scarcer they are $(\eta>1)$ a reduction in the supply of bank debt holdings drives down its yield. This can lead to a fall in banks' overall funding costs. The larger $\eta$, the larger the sensitivity of the interest rate $r$ to changes in $s$.

A reduction in leverage lowers the marginal subsidy from risk-taking in equation (21), causing banks to choose lower levels of $\sigma^{h}$. This is due to the complementarity between banks' risk choice and leverage. A reduction in $\sigma^{h}$ leads to an increase in the mean productivity level of banks' investment technology. This raises the marginal product of risky assets. Outside the steady state, lower levels of $\sigma^{h}$ imply a lower variance of bank dependent output and thus total output. ${ }^{29}$

Both the reduction in funding costs and the increase in the marginal product make risky assets more desirable. For this reason banks want to increase their risky asset holdings. Higher productivity and a higher stock of risky assets increase the capital stock of the

\footnotetext{
${ }^{29}$ If the government could credibly commit to not bail out the banks, the incentives for excessive risktaking would be void and the model's optimal capital requirement would be zero. The paper is silent on why these government bailout guarantees exist. The literature makes the case for both inefficient (e.g. Chari and Kehoe (2013)) and efficient (e.g. Jeanne and Korinek (2013)) bailouts. Bianchi (2012) analyzes the trade-off between bailouts and ex-ante risk taking. The present paper focuses on the capital requirement as the only policy tool because it is arguably more time-consistent.
} 
economy and the output from the bank dependent part of production. As a consequence, overall output and consumption increase. The optimal capital requirement trades off the fall in liquidity in the form of bank debt against the rise in consumption. When shocks are included in the analysis, the optimal capital requirement also takes into account the reduction in output volatility.

\section{Key Parameters}

The magnitude of the fall in $r$ depends on the curvature parameter $\eta$ in the utility function of the households. In addition to $\eta$, the curvature parameter in the banking sector technology $v$ matters for how much banks increase their assets in response to tighter requirements. The larger $v$ is, the easier assets are transformed into bank dependent output and therefore the larger the effect on consumption will be. The other two parameters that matter are $\omega_{2}$ and $\phi_{2}$ which together affect the optimal risk choice of banks. A high value for $\omega_{2}$ implies a larger sensitivity of the subsidy with respect to risk-taking. A high value of $\phi_{2}$ means that the productivity level $Z^{h}$ decreases faster in risk taking. In the next section, I present how the model is matched to the data.

\section{Mapping the Model to the Data}

The model is calibrated for the United States at quarterly frequency from the first quarter of 1999 to the last quarter of 2013. This period reflects a deregulated banking system which arguably started with the passing of the Gramm-Leach-Bliley Act. ${ }^{30}$ The firm parameters are calibrated using NIPA data while bank parameters are calibrated using data from commercial banks and savings institutions. This data stems from aggregated regulatory filings, so called call reports, which comprise balance sheet and income statement data. ${ }^{31}$ The dollar quantities are converted to trillion of dollars and normalized by the St. Louis Fed population numbers measured in billions.

\subsection{Choosing Parameters}

The calibrated parameters can be divided into three groups. The first group (summarized in table 2) are parameters that are directly set to their data counterpart. The second group of parameters (summarized in table 3) uses moments in the data together with the steady state

\footnotetext{
${ }^{30}$ In 1996, the Federal Reserve reinterpreted the Glass-Steagall Act several times, eventually allowing bank holding companies to earn up to 25 percent of their revenues in investment banking. But it was not until 1999 that the Glass-Steagall Act was completely repealed with the Gramm-Leach-Bliley Act.

${ }^{31}$ http://www.fdic.gov/bank/statistical/guide/index.html
} 
conditions of the model to identify the parameters. The remaining parameters determine second moments of the model (summarized in table 4) which are jointly calibrated with the other parameters in table 3. This leaves several other second moments which can be used to check the model. For example, I can check the model against business cycle moments and cross-correlations of balance sheet and income statement variables that have not been targeted. I will now explain in more detail how each parameter is calibrated. ${ }^{32}$

One important question for the quantification of this model is what the data counterpart of bank output is. GDP can be measured with the value added, expenditure, or income approach. Bank income is thus part of GDP and can be viewed as the value added from the banking sector. In the model, bank dependent output is produced with capital and banks are able to extract all rents. In this case, rents to capital in the bank dependent part of production equal the income of banks. The calibration uses this analogy and measures bank dependent production output as the sum over interest and non-interest income net of interest income from securities using the aggregated income statements of commercial banks and savings institutions. The value added by firms is measured as the difference between total GDP from NIPA tables and banks' value added. According to this measure banks account for roughly $5 \%$ of GDP. ${ }^{33}$ An overview on how model objects are mapped to the data is given in table 1.

For capital used in bank production, I use banks' risky assets from the balance sheet: total assets net of government securities, fixed assets, and cash. This capital measure of banks implies a capital-output ratio of roughly 12. Using the data on risky assets of banks as well as interest and non-interest income, the decreasing return to scale parameter $v=0.3$ matches the income-risky asset ratio in the data. This parameter governs how much bank dependent output can be generated with one unit of risky assets. In the model, the amount of government debt $B$ is exogenous. I set $B$ to the average level of riskless assets on banks' balance sheets which consist mainly in government securities and cash. The average of riskless assets amounts to $\$ 15.571$.

The depreciation rate in the bank dependent sector $\delta^{h}$ is set such that the economy's resource constraint is satisfied. I use the economy wide (average) depreciation rate, using gross investment data and data on capital consumption from the NIPA, to back out the depreciation rate in the firm sector.

\footnotetext{
${ }^{32}$ The web appendix describes the calibration strategy in great detail.

${ }^{33}$ The assumption that banks can extract all the rents from bank dependent production results in a conversative estimate for how important banks are for the economy. The bank independent sector value added is computed as the residual of total GDP and bank sector value added. Suppose that banks cannot capture all the rents from bank dependent production. In this case, I assign too much value added to the non-bank dependent sector. The benefits from capital requirements regulation with regard to lending are consequently understated as they affect a relatively smaller part of the economy.
} 
The average capital-output ratio is 7.26 , which implies a consumption-capital ratio of about 0.11 . The capital-output ratio of firms is 7 . The firm Cobb-Douglas function parameter $\alpha$ is chosen to match the share of salaries and wages in GDP, which gives $\alpha=0.33$. The growth rate $\Gamma$ is computed using real GDP which results in an annualized growth rate of $3 \%$. The time preference rate $(\beta=0.977)$ is picked such that it is consistent with the steady state investment optimality condition as well as the marginal product of firm capital. In the model, households supply labor inelastically. I use this fact to normalize hours worked to a constant, using the hours series constructed and kept updated by Cociuba, Ueberfeldt, and Prescott $(2012)^{34}$. The number of average hours worked in the firm sector is around 1433 hours (at an annual rate), so $N^{f}=1.43$. For the parameters and firm sector size to match the restriction of the Cobb-Douglas function, I convert hours into effective hours. In the model, I call this parameter $E^{f}$, which is roughly 18 . In order to parametrize the productivity process $Z^{f}$ of firms, I decompose GDP into its factor components. Then I apply the HP filter to the series and calculate its standard deviation which gives $\sigma^{f}=0.0071$. I take the persistence parameter from the literature which typically sets a value of $\rho^{f}=0.95$.

The parameter $\xi$ denotes the Tier-1 capital requirement in the model. According to the FDIC rules, banks are deemed well capitalized if they hold a 6 percent Tier-1 capital (common stock, noncumulative perpetual preferred stock, and minority interests in consolidated subsidiaries) to risk-weighted asset ratio. On average, banks hold $10.88 \%$ of risky assets (measured here as assets net of fixed assets, government securities, and cash) in terms of Tier-1 equity (common stock, noncumulative perpetual preferred stock, and minority interests in consolidated subsidiaries), so that $\xi=10.88 \%$.

Now I describe the calibration of the parameters governing the government subsidy and the risk-return frontier in the productivity process of $y^{h}$ as well as the preference parameters for bank debt holdings. These parameters are essential for the behavior of banks and specific to this model. The scalar $\omega_{3}$ in the subsidy function is calibrated so that the subsidy without the benefit for leverage and risk-taking equals the tax-benefit on debt per unit of risky assets:

$$
\text { Tax Advantage }=T R\left(1, \frac{\tilde{e}}{k^{h}}, \sigma^{h} \mid \omega_{1}=0, \omega_{2}=0\right)=\omega_{3} \exp \left(-0 \times \frac{\tilde{e}}{k^{h}}+0 \times \sigma^{h}\right)
$$

Graham (2000) estimated the tax benefit of debt to be $4.3 \%$ (net of personal taxes) of firm market value. The ratio of banks' market value to risky assets is approximately 0.10. Thus the tax benefit of debt per dollar of risky assets is on the magnitude of 0.43 cents, giving $\omega_{3}=0.0043$.

\footnotetext{
${ }^{34}$ The data can be downloaded from Simona Cociuba's website: https://sites.google.com/site/simonacociuba/research.
} 
I obtain an estimate for $T R\left(1, \frac{\tilde{e}}{k^{h}}, \sigma^{h}\right)$ from the model by finding $T R\left(1, \frac{\tilde{e}}{k^{h}}, \sigma^{h}\right)$ as the difference from profits in the model to profits in the data which results in $T R\left(1, \frac{\tilde{e}}{k^{h}}, \sigma^{h}\right)=27$ basis point. I find the sensitivity of the transfer function with respect to $\omega_{1}$ by targeting bank profits in the steady state, resulting in $\omega_{1}=5.015$. The scalar $\omega_{1}$ takes on large values when banks operate at a low marginal product and high capital intensity levels, and when they are highly leveraged.

The parameters $\omega_{2}$ and $\phi_{2}$ determine the risk choice of banks. The parameter $\omega_{2}$ governs how much risk banks want to take because of the subsidy, whereas the parameter $\phi_{2}$ governs how much risk reduces the productivity of banks. The steady state conditions of the model pin only one parameter down. I identify $\phi_{2}$ using banks' optimality condition with respect to risk taking. I choose $\omega_{2}$ such that the conditional variance of the HP filtered income-asset ratio given past profits is matched. In the data, the subsidy to banks is included in profits. I infer a high value for $\omega_{2}$ if the income-asset volatility is high conditional on the profit-asset ratio being high a period ago. That is, I regress the demeaned business cycle component of the income-asset ratio on the lagged profit-asset ratio

$$
\left(\log \left(\frac{y^{\prime h}}{k^{\prime h}}\right)\right)^{2}=\text { const }+\operatorname{coefficient}\left(\pi / k^{h}\right)+\text { error, }
$$

in the data and obtain an estimate for the coefficient on $\pi / k^{h}$. Then I solve the model given $\omega_{2}$ and simulate data to find the model implied regression coefficient. I find $\omega_{2}$ such that the distance between the data target and the model counterpart is minimized.

The scalar $\phi_{1}$ matches the unconditional mean of the stationary process in $Z^{h}$. To calculate this process, I use the HP filtered business cycle component of $\log \left(y^{h} / k^{h}\right)$. The parameter $\rho^{h}$ equals the autocorrelation of this series. The unconditional mean of a demeaned and stationary process is

$$
E\left(Z^{h}\right)=0=\exp \left(\frac{\phi_{1} \sigma^{h}-\phi_{2}\left(\sigma^{h}\right)^{2}}{1-\rho^{h}}+\frac{\left(\sigma^{h}\right)^{2}}{2}\right) .
$$

Given an observed volatility of banks, $\phi_{2}$ controls where the unconditional mean $Z^{h}$ reaches its maximum. This parameter is chosen to satisfy the first order condition of banks with respect to risk taking $\sigma^{h}$ while at the same time satisfying the restriction of the unconditional mean of $Z^{h}$. A higher value for $\phi_{2}$ implies a lower productivity maximizing amount of risk as $\sigma^{* h}=\phi_{1} / 2 \phi_{2}$. For the calibration, $\sigma^{h}$ is set to the volatility of the income to risky assets ratio. Figure 2 depicts the conditional mean of $Z^{h}$ with the calibrated parameters $\phi_{1}=0.1336$ and $\phi_{2}=0.895$. 
Households have log utility with respect to consumption for simplicity. The preferences for bank liabilities are governed by parameters $\eta$ and $\theta$. The parameter $\theta$ determines the interest rate discount on bank liabilities. I select $\theta$ to match the interest rate discount using the first order conditions of the model. More concretely given $\eta$, the scalar $\theta$ is identified by the first order condition of households with respect to bank debt holdings in steady state (see equation 18). The interest rate on bank debt is on average $0.39 \%$ (annualized). The return on equity in the steady state is $1+r^{e}=1 / \beta \Gamma^{-1}$, which implies a $\theta$ value of 0.0203 .

The parameter $\eta$ determines the curvature in the utility of the bank debt holdings

to consumption ratio. As such, it determines how much this ratio varies. Naturally, the target moment in the data to calibrate $\eta$ is the volatility of the bank debt holdings to consumption ratio. I choose $\eta$ jointly with the other second moment parameters (government subsidy sensitivity to risk-taking $\omega_{2}$ and the adjustment costs parameters $\varphi_{f}, \varphi_{h}$, and $\kappa$ ) to minimize the average distance (relative to GDP) between the volatility of bank investment as well as aggregate investment, the volatility of dividend, the volatility of the bank debt holdings to consumption ratio, and the conditional income-asset ratio volatility and their data counterparts. Table 5 presents the targeted relative standard deviations in the model and contrasts them with the data. The parameter values that jointly minimize the difference to the data with regard to investment, dividend, and $s / c$ volatilities are $\omega_{2}=2.92, \kappa=0.0001$, $\varphi_{h}=0.0774, \varphi_{f}=0.14$, and $\eta=3.15$.

\subsection{Business Cycle Statistics}

In this section, I discuss the business cycle implications of the model. The model is solved using local perturbation methods (see Tommaso Mancini Griffoli's Dynare user guide) with the benchmark calibration where $\xi=10.88 \%$. I simulate the model 1500 times for twice as many periods as are in my sample (roughly 120). Half of the observations are discarded. Then I apply the HP filter with a smoothing parameter of 1600 to the remaining simulated data points. I use this data to compute volatilities and correlations that are reported in tables 8 and 6 .

Table 8 reports the volatilities of key variables in the model. In the model, GDP is almost as volatile as in the data which is largely driven by the volatility of the banking sector. The model captures the volatility of assets, bank debt, and bank profits. It overstates the volatility of bank income and understates the volatility of consumption. This model is in essence a one factor model that is calibrated to match the volatility of the ratio $y^{h} / k^{h}$. This makes it difficult for the model to match the volatility of both, the level of $k^{h}$ and the level of $y^{h}$. This does not matter for the results, as households care about the volatility of 
consumption and the volatility of bank liabilities to consumption, which is matched by the model. The low consumption volatility is a familiar feature of many business cycle models.

Table 6 summarizes the business cycle - and cross-correlations of the model and compares it to the data. Overall, it produces reasonable correlations, in particular regarding the business cycle correlations, which can be seen in the first column of table 6 . The model is able capture the correlation between bank debt holdings and consumption in the data. Consumption and total investment comove with GDP because the marginal product on capital is higher during booms, leading to better investment opportunities and higher output during booms. Banking output and balance sheet variables are procyclical as in the data. The curvature on the deposit-consumption ratio in the utility $\eta$ and the adjustment costs of capital in both sectors are important ${ }^{35}$ for producing the procyclicality of banking sector variables. $^{36}$

Since banks are at the capital constraint, movements in bank capital stock $k^{h}$ are perfectly correlated with movements in bank debt $s$. Relatively inelastic preferences for the bank debt holdings to consumption ratio therefore represent another reason for a slow response of $k^{h}$ to shocks. In a boom, agents want to consume more and with $\eta>1$, they also demand more liquidity from banks. As a result, the model is able to generate a positive correlation between bank investment and aggregate investment.

Since bank debt holdings are procyclical, the interest rate on bank debt is procyclical, too. The model captures these procyclicalities. Movements in the interest rate come from movements in the ratio of marginal utilities of bank debt and consumption. Since bank debt is procyclical the marginal utility of bank debt is countercyclical, inducing comovement of the interest rate on bank debt rates with GDP.

The model generates similar business cycle correlations of bank output, investment, assets, deposits, dividends, return over risky assets, and bank investment as in the data. Good times increase profits for banks because the marginal product of risky assets increases. The higher profitability of banks during booms implies lower payoffs of the government subsidy whose value is higher during bad times. When the payments from the subsidy are

\footnotetext{
${ }^{35}$ The positive correlation between banking and firm sector productivity plays a minor role for generating the pro-cyclicality of banking sector variables. The business cycle statistics for the case when $\rho_{h k}=0$ are essentially identical to the baseline calibration where $\rho_{h k}>0$.

${ }^{36}$ When $\eta$ takes on a large value, households are less flexible with regard to changes in the bank debt holdings-consumption ratio. When only the firm sector is hit by a positive shock, the marginal product of firm capital $k^{f}$ is higher. This raises the opportunity costs for $k^{h}$ and the rate at which shareholders want to be compensated. Without adjustment costs to capital or relatively strong curvature in the preferences for the bank debt holdings to consumption ratio, risky assets of banks flow immediately to firms at times when the productivity of capital in the firm sector is higher than in the banking sectors, producing a negative correlation between balance sheet variables and total GDP. Adjustment costs make it expensive to change the current stock of capital in either sector and therefore slow down the response to shocks.
} 
lower, banks have less incentive to take on excessive risks so that they choose less risky and more efficient projects, which increases profits and lowers the subsidy further. The return over risky assets is governed by the marginal product of risky assets and therefore procyclical. Dividends are essentially a function of profits and thus pro-cyclical.

Overall, the model is able to produce the correct signs of the correlations besides the following exceptions. The correlations of equity with balance sheet variables appear more procyclical in the model than in the data for the calibration sample (1999-2014). ${ }^{37}$ In the model, risky assets and book equity are perfectly correlated because banks are constrained by the capital requirement. This is consistent with the data where the ratio of equity to assets is acyclical, implying that equity expands along with assets during booms. The model fails to capture the negative correlation between profits and assets (as well as deposits and risky assets). The model produces excessive comovement of profits with GDP. Since assets and profits move together along the business cycle, they also exhibit a positive cross-correlation.

\section{Welfare}

In this section, I discuss how a regulator should optimally set the capital requirement of banks. To solve the model, I use local perturbation methods (see Tommaso Mancini Griffoli's Dynare user guide).

\section{Optimal Capital Requirement}

I solve for the equilibrium presented in section 2.5 for different levels of capital requirement and obtain its decision rules. Next, I simulate the model under the benchmark capital requirement of $\xi=10.88 \%$. In order to find the optimal requirement taking into account the transition effects, I use the decision rules for each value of $\xi$ to simulate time paths for consumption and bank debt, starting at a random point on the time path of the benchmark capital requirement. This procedure is repeated over the number of simulations, starting the new regime each time at a different point on the old regime's time path. Then - for each $\xi$ I evaluate the realized utility and compute the value function for the period before the new regime is introduced by discounting the time path of utility with households' pricing kernel. Finally, I average across simulations.

\footnotetext{
${ }^{37}$ When computing the correlation between equity and assets in the data for the longer period from 1984 to 2013 (see the web appendix section C.1), the correlation is significantly positive.
} 
Figure 4 depicts the result expressed in consumption equivalent percentage units, that is, the percentage permanent change in consumption if the economy moves from the current regime $(\xi=10.88 \%)$ to any capital requirement on the $\mathrm{x}$-axis. The value function reaches its maximum at about $\xi=14 \%$, which is above the level that commercial banks and savings institutions currently hold on their balance sheet.

When the capital requirement is increased, banks reduce the supply of bank debt and increase equity as shown in figure 7 . This figure presents the time path of bank debt (left panel) and equity (right panel) for different levels of capital requirement over the transition periods. Banks can comply with the higher level of capital requirement by either keeping equity constant and reducing bank debt, or by increasing equity and expanding assets. But even in the latter case, banks need to reduce bank debt because a balance sheet expansion must go through the decreasing returns to scale on banks' asset side. The only way to entice banks to become larger is through a reduction in the funding costs of assets. Without reducing the supply of bank debt though, the cost of bank debt remains unchanged. The return on equity decreases with an increase in $\xi$ because equity becomes less risky. However banks are also required to finance a larger share of their assets with relatively more expensive equity. Thus, the increase in $\xi$ leads to an increase in the total cost of assets to which banks respond by deleveraging.

The reduction in the supply of bank debt affects the interest rate as discussed in section 3.2. The fall in the interest rate on bank debt leads to overall lower funding costs of banks as shown in figure 5. This entices banks to increase their size financed by more equity (as seen in the right panel of figure 7). The increase in size also prevents the supply of bank debt from falling too much. ${ }^{38}$

The increase in bank assets and equity occurs relatively quickly because the adjustment costs to capital and dividends are low. However, it takes time to expand the balance sheet because capital (necessary for the balance sheet expansion) accumulates slowly over time. Figure 7 shows the time path of capital in the banking sector (left panel) and non-banking sector (right panel). Only for a high value of the capital requirement, say $\xi=22 \%$, banks need to initially lower their assets.

As described in section 3.2, banks not only increase risky assets, they also employ them more efficiently through a reduction in risk-taking (see right panel of figure 7 ). The choice of $\sigma^{h}$ implies a trade-off between the benefit from the subsidy and the loss in efficiency (reduction in the expected mean $Z^{h}$ ). The capital requirement lowers the benefit from the

\footnotetext{
${ }^{38}$ The higher the levels of $\xi$, the larger the fall in bank debt holdings and their rate. That is, for high values of $\xi$, say $22 \%$, households accept a larger reduction in the interest rate, which prevents the supply of bank debt from falling too much.
} 
subsidy which entices banks to take on more efficient levels of risk.

An increase in overall output increases consumption (see the left panel of figure 7). The optimal capital requirement trades off the fall in utility due to the reduction in deposits against the rise in utility through a reduction in economic volatility and higher consumption levels.

\section{How does the Economy behave under the Optimal Capital Requirement}

Table 9 shows how the benchmark economy (averaged over simulations and time paths) under $\xi=10.88 \%$ differs from the economy under $\xi=14 \%$. The first row of each block in table 9 presents the percentage difference in average levels between the new and the old regime. The second row presents the average difference in the standard deviations.

Households prefer the higher capital requirement regime over the current one because it leads to higher consumption $(+0.09 \%)$ and lower volatility $(-3.87 \%)$ in consumption. To reach this new level of capital requirement, they accept a $2.70 \%$ reduction in the holding of bank debt. Banks also profit from an increase in the capital requirement. The fall in the funding costs, driven by a $22.5 \%$ reduction in the rate on bank debt, increases profits per unit of capital by $6.71 \%$. Table 9 shows that higher capital requirements do not necessarily imply a fall in output, bank activity, or bank profits. The reason for this is the general equilibrium effect that changes the funding costs of assets. If the capital requirement is not increased by too much, the increase in the capital requirement leads to a reduction in the funding costs of banks.

The reduction in banks' risk-taking by $11 \%$ means that risk-taking is decreased by 1 percentage point. This drives the fall in the standard deviation of output. It also increases the productivity of banks by $1.71 \%$. Banks' output increases because they are more productive and employ more capital in the production process. To comply with the higher requirement, banks need to increase equity by about $26 \%$.

\section{Welfare Gain of Optimal Capital Requirement}

In the spirit of Lucas (1987), I compute the welfare cost of current capital requirement as the percentage change in consumption needed to make households indifferent between the current regime and the optimal regime in case of an immediate implementation. That is, I find the scalar $\lambda_{0}$ that keeps households indifferent between

$$
E_{0}\left(\sum_{t=0}^{\infty} M_{t+1} U\left(\left(c_{t}, s_{t}\right) \mid \xi=10.88 \%\right)\right)=E_{0}\left(\sum_{t=0}^{\infty} M_{t+1} U\left(\left(\lambda_{0} c_{t}, s_{t}\right) \mid \xi=14 \%\right)\right),
$$

starting from their respective steady states. The $\lambda_{0}$ that makes households indifferent be- 
tween the two regimes is 0.99975 . In other words, households are indifferent between the old regime and the new regime, if they accept a permanent reduction of $0.025 \%$ (quarterly) in consumption. This is a small improvement in welfare which is common in the literature (see Lucas (1987) and Van Den Heuvel (2008)).

\section{When to Increase the Capital Requirement}

In this exercise, the transition to the new capital requirement is started during a recession (solid line in figure 6) and alternatively in a boom (dashed line in figure 6). A crisis is defined as a below average shock in both sectors over at least three quarters and a boom is defined as an above average shock in both sectors over at least three quarters. The model implies that welfare is maximized at a higher capital requirement when the policy is introduced during a recession than during a boom. Banks increase loan supply when funding costs decrease. Higher capital requirements trigger a larger fall in bank debt and therefore a larger fall in the funding costs of banks. During a recession, banks should be enticed to lend more even though current profits are low. The way to convince banks to increase their assets despite low returns is by reducing the funding costs of banks through a higher level of the capital requirement.

\section{Conclusion}

This paper has developed a quantitative dynamic general equilibrium model to study the effects of capital requirements on the economy and to determine the optimal level. The safety and liquidity premium on the price of bank debt changes the standard intuition for the effect on bank lending of capital requirements.

The reduction in bank debt as a response to a higher capital requirement leads to an increase in the demand for bank debt. The increased demand drives down the yield on bank debt, a general equilibrium effect, leading to lower funding costs for banks. This motivates banks to increase their loan supply, increasing output and consumption.

In the model, the regulation forces all banks to collectively increase their equity to risky asset ratio. This increases the scarcity of safe and liquid assets in the economy and therefore reduces the funding costs of banks through the general equilibrium effect. Therefore, an important avenue for future research is to model a financial system in which some entities are not regulated or only partially regulated. This paper's intuition suggests that the change in funding costs of banks due to an increase in the capital requirement will be a function of the ability of the unregulated banking sector to substitute safe and liquid assets provided by the regulated banking sector. It will be important for regulatory proposals to measure the 
degree to which this substitution can take place.

Interestingly, since the first draft of this paper circulated, policy makers and regulators are indeed seriously considering to raise the capital requirement to11.5 and thus towards the optimal requirement implied by the quantitative model in this paper. In the coming years, we will be able to observe whether the capital requirement will increase even further. 


\section{References}

Admati, A., P. DeMarzo, M. Hellwig, and P. Pfleiderer (2012). Debt overhang and capital regulation.

Admati, A. and M. Hellwig (2013). The Bankers' New Clothes: What's Wrong with Banking and What to Do about It. Princeton University Press.

Adrian, T. and H. S. Shin (2011). Financial Intermediary Balance Sheet Management.

Allen, F. and E. Carletti (2013). Deposits and bank capital structure.

Begenau, J., M. Piazzesi, and M. Schneider (2013). Banks' Risk Exposures.

Bernanke, B. S. (2005). The global saving glut and the us current account deficit. Technical report.

Bernanke, B. S. and M. Gertler (1989, February). Agency Costs, Net Worth, and Business Fluctuations. The American Economic Review 79, 14-31.

Bernanke, B. S., M. Gertler, and S. Gilchrist (1999). The Financial Accelerator in a Quantitative Business Cycle Framework. In Handbook of Macroeconomics, Volume 1, pp. 13411393.

Bianchi, J. (2012). Efficient bailouts? Technical report, National Bureau of Economic Research.

Black, F. and M. Scholes (1973). The Pricing of Options and Corporate Liabilities. Journal of Political Economy 81 (3), pp. 637-654.

Brunnermeier, M. K. and Y. Sannikov (2012). A Macroeconomic Model with a Financial Sector.

Chari, V., L. Christiano, and M. Eichenbaum (1995). Inside Money, Outside Money and Short Term Interest Rates.

Chari, V. and P. J. Kehoe (2013, June). Bailouts, time inconsistency, and optimal regulation. Working Paper 19192, National Bureau of Economic Research.

Christiano, L. and D. Ikeda (2013). Leverage Restrictions in a Business Cycle Model.

Christiano, L., R. Motto, and M. Rostagno (2010). Financial Factors in economic Fluctuations. 
Clerc, L., A. Derviz, C. Mendicino, S. Moyen, K. Nikolov, L. Stracc, and J. Suarez (2014). Capital regulation in a macroeconomic model with three layers of default. Technical report.

Cociuba, S. E., A. Ueberfeldt, and E. C. Prescott (2012). U.S. Hours and Productivity Behavior Using CPS Hours Worked Data: 1947-III to 2011-IV S.

Corbae, D. and P. D'Erasmo (2012). Capital Requirements in a Quantitative Model of Banking Industry Dynamics.

De Nicolò, G., A. Gamba, and M. Lucchetta (2014). Microprudential regulation in a dynamic model of banking. Review of Financial Studies.

DeAngelo, H. and R. Stulz (2013). Why High Leverage is Optimal for Banks.

Dewatripont, M. and J. Tirole (1994). A Theory of Debt and Equity: Diversity of Securities and Manager-Shareholder. The Quarterly Journal of Economics 109(4), 1027-1054.

Diamond, D. W. (1984, July). Financial Intermediation and Delegated Monitoring. The Review of Economic Studies 51, 393.

Diamond, D. W. and P. H. Dybvig (1983). Bank Runs, Deposit Insurance, and Liquidity. Journal of Political Economy $91(3), 401-419$.

Diamond, D. W. and R. G. Rajan (2000). A Theory of Bank Capital. Journal of Finance $L V(6), 2431-2465$.

Diamond, D. W. and R. G. Rajan (2001, April). Liquidity Risk, Liquidity Creation, and Financial Fragility: A Theory of Banking. Journal of Political Economy 109(2), 287-327.

Dickens, R. N., K. M. Casey, and J. A. Newman (2002). Bank Dividend Policy: Explanatory Factors. Quarterly Journal of Business and Economics 41(1), 3-12.

Feenstra, R. C. (1986). Functional Equivalence between Liquidity Costs and the Utility of Money. Journal of Monetary Economics 17, 271-291.

Freixas, X. and J.-c. Rochet (1998). Microeconomics of Banking. MIT Press, Cambridge, Massachusetts.

Gandhi, P. and H. Lustig (2010). Size Anomalies in US Bank Stock Returns: A Fiscal Explanation.

Gollier, C., P.-F. Koehl, and J.-c. Rochet (1997). Risk-Taking Behavior with Limited Liability and Risk Aversion. Journal of Risk and Insurance 64(2), 347-370. 
Goodhart, C. A. E., A. P. Vardoulakis, A. K. Kashyap, and D. P. Tsomocos (2012). Financial Regulation in General Equilibrium.

Gorton, G., S. Lewellen, and A. Metrick (2012). The safe-asset share. The American Economic Review 102(3), 101-106.

Gorton, G. and G. Pennacchi (1990). Financial Intermediaries and Liqduity Creation. The Journal of Finance 45(1), 49-71.

Gorton, G. and A. Winton (1995). Bank Capital Regulation in General Equilibrium.

Gourinchas, P.-O. and O. Jeanne (2012). Global safe assets.

Graham, J. R. (2000). How Big Are the Tax Benefits of Debt? Journal of Finance LV(5), 1901-1942.

Hanson, S. G., A. Shleifer, J. C. Stein, and R. W. Vishny (2014, July). Banks as patient fixed-income investors. Working Paper 20288, National Bureau of Economic Research.

Hanson, S. G., J. C. Stein, and A. K. Kashyap (2010). An Analysis of the Impact of "Substantially Heightened" Capital Requirements on Large Financial Institutions.

Harris, M., C. C. Opp, and M. M. Opp (2014). Macroprudential bank capital regulation in a competitive financial system.

Hennessy, C. A. and T. M. Whited (2007). How Costly Is External Financing ? Evidence from a Structural Estimation. The Journal of Finance LXII(4).

Holmström, B. and J. Tirole (2011). Inside and outside liquidity. The MIT Press.

Jeanne, O. and A. Korinek (2013, January). Macroprudential regulation versus mopping up after the crash. Working Paper 18675, National Bureau of Economic Research.

Jermann, U. and V. Quadrini (2012). Macroeconomic Effects of Financial Shocks. American Economic Review 102(1), 238-271.

Kashyap, A. K., R. G. Rajan, and J. C. Stein (2008). Rethinking capital Regulation. In Federal Reserve Bank of Kansas City Symposium on Maintaining Stability in a Changing Financial System, pp. 431-471.

Kiyotaki, N. and J. Moore (1997). Credit Cycles. Journal of Political Economy 105(2), 211-248. 
Krishnamurthy, A. and A. Vissing-Jorgensen (2012). The aggregate demand for treasury debt. Journal of Political Economy 120(2), 233-267.

Lintner, J. (1956). Distribution of Incomes of Corporations Among Dividens, Retained Earnings, and Taxes. The American Economic; Papers and Proceedings of the Sixtyeighth Annual Meeting of the American Economic Association 46(2), 97-113.

Lucas, R. E. (1987). Models of business cycles, Volume 26. Basil Blackwell Oxford.

Marshall, D. A. and E. S. Prescott (2006). State-contingent bank regulation with unobserved actions and unobserved characteristics. Journal of Economic Dynamics and Control 30 (11), 2015-2049.

Martinez-Miera, D. and J. Suarez (2014). Banks' endogenous systemic risk taking.

Nguyen, T. T. (2014). Bank capital requirements: A quantitative analysis. Technical report, Carnegie-Rochester Conference Series on Public Policy, Forthcoming.

Peek, J. and E. Rosengren (1995). Bank regulation and the credit crunch. Journal of Banking and Finance 19(34), 679 - 692. The Role of Capital in Financial Institutions.

Pennacchi, G. (2006, January). Deposit insurance, bank regulation, and financial system risks. Journal of Monetary Economics 53(1), 1-30.

Poterba, J. M. and J. J. Rotemberg (1986). Money in the Utility Function: An Empirical Implementation.

Schneider, M. and M. Doepke (2013). Money as a Unit of Account.

Schneider, M. and A. Tornell (2004, July). Balance Sheet Effects, Bailout Guarantees and Financial Crises. Review of Economic Studies 71(3), 883-913.

Sharpe, S. A. (1990). Asymmetric Information, Bank Lending, and Implicit Contracts: A Stylized Model of Customer Relationships. The Journal of Finance 45(4), 1069-1087.

Sidrauski, M. (1967). Inflation and Economic Growth. Journal of Political Economy 75(6), 796-810.

Tirole, J. and B. Holmstrom (1997). Financial Intermediation, Loanable Funds, and the Real Sector. The Quarterly Journal of Economics CXII(August).

Van Den Heuvel, S. J. (2008, March). The welfare cost of bank capital requirements. Journal of Monetary Economics 55(2), 298-320. 
Table 1: Mapping the Model to the Data

\begin{tabular}{|l|l|}
\hline Model & NIPA and FDIC balance sheet \& income statement \\
\hline$y^{h}:$ bank output & income- securities interest income \\
$k^{h}:$ bank capital & assets - sec-cash - fixed assets \\
$y^{f}:$ firm output & NIPA total GDP - bank output \\
$k^{f}:$ firm capital & NIPA $K-k^{h}$ \\
$c:$ consumption & NIPA consumption \\
$s:$ bank debt & bank liabilities \\
$\pi:$ profits & net income + non interest expense \\
$r:$ rate on bank debt & interest expenses / bank liabilities \\
$\sigma^{h}:$ risk choice & STD of HP-filtered log $\left(y^{h} / k^{h}\right)$ \\
$e:$ equity & Tier-1 equity \\
\hline \multicolumn{2}{|l|}{ This table presents the model objects in the left and their data analogue in the right column. } \\
\hline
\end{tabular}


Table 2: Parameters selected without Steady State Conditions

\begin{tabular}{|c|c|c|}
\hline & Parameter Function & Target Moment \\
\hline$\Gamma=1.0076$ & average growth rate p.c. & p.c. quarterly GDP growth \\
\hline$\delta=0.0213$ & capital depreciation & NIPA capital consumption \\
\hline$\delta^{f}=0.0213$ & bank depreciation rate & $\delta$ is weighted average of $\delta^{f}$ and $\delta^{h}$ \\
\hline$\rho^{f}=0.95$ & \multirow{2}{*}{$z^{f}$ productivity process } & firm TFP persistence - from literature \\
\hline$\sigma^{f}=0.0071$ & & firm TFP volatility \\
\hline$N^{f}=1.43$ & average hours $(1 / 1000)$ & hours: Simona Cociuba \\
\hline$B=15.571$ & riskless securities & bank balance sheet riskkless assets \\
\hline$\rho^{h}=0.75$ & persistence of $Z^{h}$ & persistence of HP-filtered $\log \left(y^{h} / k^{h}\right)$ \\
\hline$\sigma^{f h}=0.3927$ & corr: $\epsilon^{h}$ and $\epsilon^{f}$ & corr: TFP and HP-filtered $\log \left(y^{h} / k^{h}\right)$ \\
\hline$\omega_{3}=0.0043$ & transfer parameter & tax benefit of debt $4.3 \%$ - Graham (2000) \\
\hline
\end{tabular}

This table present the parameter values that have been selected to match the moments in the right column.

Table 3: Parameters Selected Using Steady State Condition

\begin{tabular}{|c|c|c|}
\hline Parameter & Function & Target Moment \\
\hline$\alpha=0.3323$ & firm production & \multirow{10}{*}{$\begin{array}{l}\text { firm labor share in firm GDP } \\
\text { capital output ratio in firm sector } \\
\text { bank investment } \\
\text { matches Cobb Douglas } y^{f} \\
\text { income-asset } \\
\text { averages Tier-1 capital over risk-based assets } \\
\text { interest rate spread on deposits } \\
\text { bank profits } \\
\text { normalizes mean productivity level }=1 \\
\left.\text { std(HP filtered } \log \left(y^{h} / k^{h}\right)\right)=0.131\end{array}$} \\
\hline$\beta=0.9770$ & discount rate & \\
\hline$\delta^{h}=0.0214$ & firm depreciation rate & \\
\hline$E^{f}=18.354$ & effective hours & \\
\hline$v=0.2994$ & bank production & \\
\hline$\xi=10.88$ & capital constraint & \\
\hline$\theta=0.016$ & deposit utility weight & \\
\hline$\omega_{1}=5.097$ & transfer parameter & \\
\hline$\phi_{1}=0.1336$ & \multirow{2}{*}{$Z_{h}$ productivity process } & \\
\hline$\phi_{2}=0.8949$ & & \\
\hline
\end{tabular}

This table contains the parameter values that have been selected to satisfy steady state conditions of the model together with the target moments in the right column. 
Table 4: 2ND Moment Parameters

\begin{tabular}{|c|c|c|}
\hline Parameter & Function & \multirow{6}{*}{$\begin{array}{l}\text { Target Moment } \\
\frac{S t d(s / c)}{S t d(G D P)}=1.49 \\
\text { conditional variance of income-asset ratio } \\
\frac{S t d(I)}{\operatorname{Std}(G D P)}=4.42 \\
\frac{S t d\left(I_{h}\right)}{\operatorname{Std}(G D P)}=43.3 \\
\frac{S t d(d)}{\operatorname{Std}(G D P)}=25.8\end{array}$} \\
\hline$\eta=3.15$ & $s / c$ elasticity & \\
\hline$\omega_{2}=2.92$ & transfer parameter & \\
\hline$\varphi_{f}=0.14$ & Adjustment cost of $k^{f}$ & \\
\hline$\varphi_{h}=0.0774$ & Adjustment cost of $k^{h}$ & \\
\hline$\kappa=0.0001$ & Dividend payout costs & \\
\hline
\end{tabular}

This table contains parameter values that govern second moments in the model. They have been selected to match the target moments in the right column.

Table 5: Second Moment Calibration

\begin{tabular}{|c|c|c|}
\hline 1999q1 - 2011q4 & Rel. STD - D & Rel. STD - M \\
\hline \hline Dividend & 25.80 & 18 \\
\hline Investment & 4.42 & 4.40 \\
\hline Investment Bank & 43.30 & 79.23 \\
\hline Deposit/Consumption & 1.49 & 1.49 \\
\hline $\begin{array}{l}\text { This table contains the standard and the targeted relative standard } \\
\text { deviations of the data (D) and compares those to the model (M). }\end{array}$ \\
$\begin{array}{l}\text { Variables: HP-Cycle component of logged variable expressed in percent } \\
\text { †Variables: HP-Cycle component of variable }\end{array}$ \\
\hline
\end{tabular}

Figure 2: Productivity in Steady State

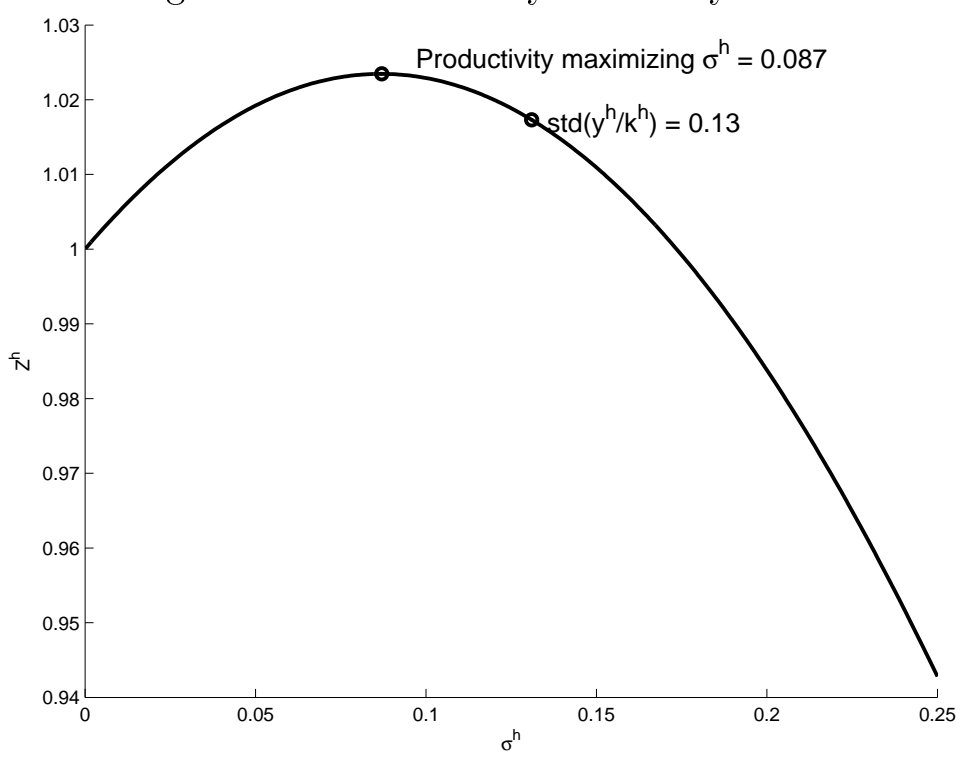


Table 6: Business Cycle Correlations (D=Data, M=Model) 1999Q1 - 2013Q4

\begin{tabular}{|c|c|c|c|c|c|c|c|c|c|c|}
\hline & \multicolumn{2}{|c|}{ GDP } & \multicolumn{2}{c|}{ Bank Output } & \multicolumn{2}{c|}{ Investment } & \multicolumn{2}{c|}{ Assets } & \multicolumn{2}{c|}{ Bank Debt } \\
\cline { 2 - 12 } & $\mathrm{D}$ & $\mathrm{M}$ & $\mathrm{D}$ & $\mathrm{M}$ & $\mathrm{D}$ & $\mathrm{M}$ & $\mathrm{D}$ & $\mathrm{M}$ & $\mathrm{D}$ & $\mathrm{M}$ \\
\hline \hline GDP & 1 & 1 & & & & & & & & \\
\hline$y^{h}$ Bank Output & 0.66 & 0.64 & 1 & 1 & & & & & & \\
\hline Investment & 0.97 & 0.98 & 0.60 & 0.70 & 1 & 1 & & & & \\
\hline Assets & 0.37 & 0.52 & 0.34 & 0.85 & 0.34 & 0.30 & 1 & 1 & & \\
\hline Bank Debt & 0.31 & 0.52 & 0.28 & 0.85 & 0.29 & 0.30 & 0.99 & 1 & 1 & 1 \\
\hline$k^{h}$ (Bank Risky Assets) & 0.57 & 0.52 & 0.59 & 0.85 & 0.52 & 0.30 & 0.91 & 1 & 0.89 & 1 \\
\hline$\tilde{e}$ Equity & 0.33 & 0.63 & 0.31 & 0.99 & 0.30 & 0.68 & $-0.07 \dagger$ & 0.89 & $-0.21 \dagger$ & 0.89 \\
\hline$d$ Dividend & 0.40 & 0.63 & 0.28 & 0.99 & 0.37 & 0.69 & $-0.19 \dagger$ & 0.83 & $-0.22 \dagger$ & 0.83 \\
\hline$\dagger \dagger \mathrm{r}$ & 0.68 & 0.55 & 0.95 & 0.86 & 0.65 & 0.63 & 0.38 & 0.88 & 0.33 & 0.88 \\
\hline$c$ Consumption & 0.94 & 0.88 & 0.71 & 0.44 & 0.90 & 0.77 & 0.31 & 0.52 & 0.25 & 0.52 \\
\hline$\pi$ Profit & 0.34 & 0.62 & 0.33 & 0.98 & 0.35 & 0.68 & -0.48 & 0.77 & -0.54 & 0.77 \\
\hline$i^{h}$ Bank Investment & 0.46 & 0.44 & 0.33 & 0.64 & 0.50 & 0.63 & $0.21 \dagger$ & 0.29 & $0.18 \dagger$ & 0.29 \\
\hline \hline
\end{tabular}

This table displays the business cycle correlations of model object (M) and compares those to their data counterpart (D).

Variables: HP-Cycle component of logged variable / GDP trend, HP smoothing $=1600$

$\dagger: \mathrm{p}$-value $>.05 ; \dagger \dagger$ Variables: HP-Cycle component variable / GDP trend

Table 7: Business Cycle Correlations 1999Q1-2013Q4

\begin{tabular}{|c|c|c|c|c|c|c|c|c|c|c|c|c|}
\hline & \multicolumn{2}{|c|}{$k^{h}$} & \multicolumn{2}{|c|}{$\tilde{e}$} & \multicolumn{2}{c|}{$\mathrm{d}$} & \multicolumn{2}{c|}{$r$} & \multicolumn{2}{|c|}{$\mathrm{c}$} & \multicolumn{2}{c|}{$\pi$} \\
\cline { 2 - 14 } & $\mathrm{D}$ & $\mathrm{M}$ & $\mathrm{D}$ & $\mathrm{M}$ & $\mathrm{D}$ & $\mathrm{M}$ & $\mathrm{D}$ & $\mathrm{M}$ & $\mathrm{D}$ & $\mathrm{M}$ & $\mathrm{D}$ & $\mathrm{M}$ \\
\hline \hline$k^{h}$ & 1 & 1 & & & & & & & & & & \\
\hline$\tilde{e}$ & $0.03 \dagger$ & 0.89 & 1 & 1 & & & & & & & & \\
\hline$d$ & $-0.03 \dagger$ & 0.83 & $0.20 \dagger$ & 0.98 & 1 & 1 & & & & & & \\
\hline$\dagger \dagger \mathrm{r}$ & 0.63 & 0.88 & $0.24 \dagger$ & 0.87 & 0.31 & 0.85 & 1 & 1 & & & & \\
\hline$c$ & 0.54 & 0.53 & 0.37 & 0.47 & 0.48 & 0.44 & 0.72 & 0.47 & 1 & 1 & & \\
\hline$\pi$ & -0.32 & 0.77 & 0.53 & 0.96 & 0.40 & 0.99 & $0.16 \dagger$ & 0.81 & 0.42 & 0.41 & 1 & 1 \\
\hline$i^{h}$ & $0.25 \dagger$ & 0.29 & $0.24 \dagger$ & 0.60 & $0.07 \dagger$ & 0.65 & 0.33 & 0.37 & 0.39 & 0.16 & 0.40 & 0.69 \\
\hline \hline
\end{tabular}

This table displays the business cycle correlations of model object (M) and compares those to their data counterpart (D).

Variables: HP-Cycle component of logged variable / GDP trend, HP smoothing $=1600$

$\dagger:$ p-value $>.05 ; \dagger \dagger$ Variables: HP-Cycle component variable / GDP trend 
Table 8: Volatilities

\begin{tabular}{|c|c|c|c|c|}
\hline 1999q1 - 2013q4 & STD - D & STD - M & Rel. STD - D & Rel. STD - M \\
\hline \hline GDP & 1.28 & 1.10 & 1 & 1 \\
\hline Bank GDP & 6.91 & 16.71 & 5.66 & 15.37 \\
\hline Assets & 1.67 & 1.84 & 1.31 & 1.69 \\
\hline Bank Debt & 1.91 & 1.79 & 1.48 & 1.64 \\
\hline Risky Assets & 3.06 & 2.49 & 2.39 & 2.29 \\
\hline Consumption & 1.04 & 0.41 & 0.81 & 0.37 \\
\hline Profits & 12.37 & 24.92 & 9.65 & 22.92 \\
\hline \hline
\end{tabular}

This table contains the standard and the relative standard deviations of the model (M) and compares those to the data (D).

Variables: HP-Cycle component of logged variable expressed in percent $\dagger$ Variables: HP-Cycle component of variable

Table 9: Percentage Change in Comparison to Old Steady State

\begin{tabular}{|c|c|c|c|c|}
\hline \% Change & Output & Cons. & Bank Output & Assets \\
\hline \hline Levels & 0.09 & 0.09 & 2.30 & 0.40 \\
\hline Std & -3.87 & -2.95 & -11.98 & -9.87 \\
\hline \hline & $\pi / k^{h}$ & Subsidy & Risk Taking & $z^{h}$ \\
\hline \hline Levels & 6.71 & -23.15 & -11.20 & 1.71 \\
\hline Std & -18.15 & -11.77 & -21.97 & -15.46 \\
\hline \hline & Equity & $k^{h}$ & Bank Debt & $r$ \\
\hline \hline Levels & 25.80 & 0.56 & -2.70 & -22.50 \\
\hline Std & -19.17 & -10.03 & -10.79 & 43.42 \\
\hline
\end{tabular}


Figure 3: Discount on Deposits

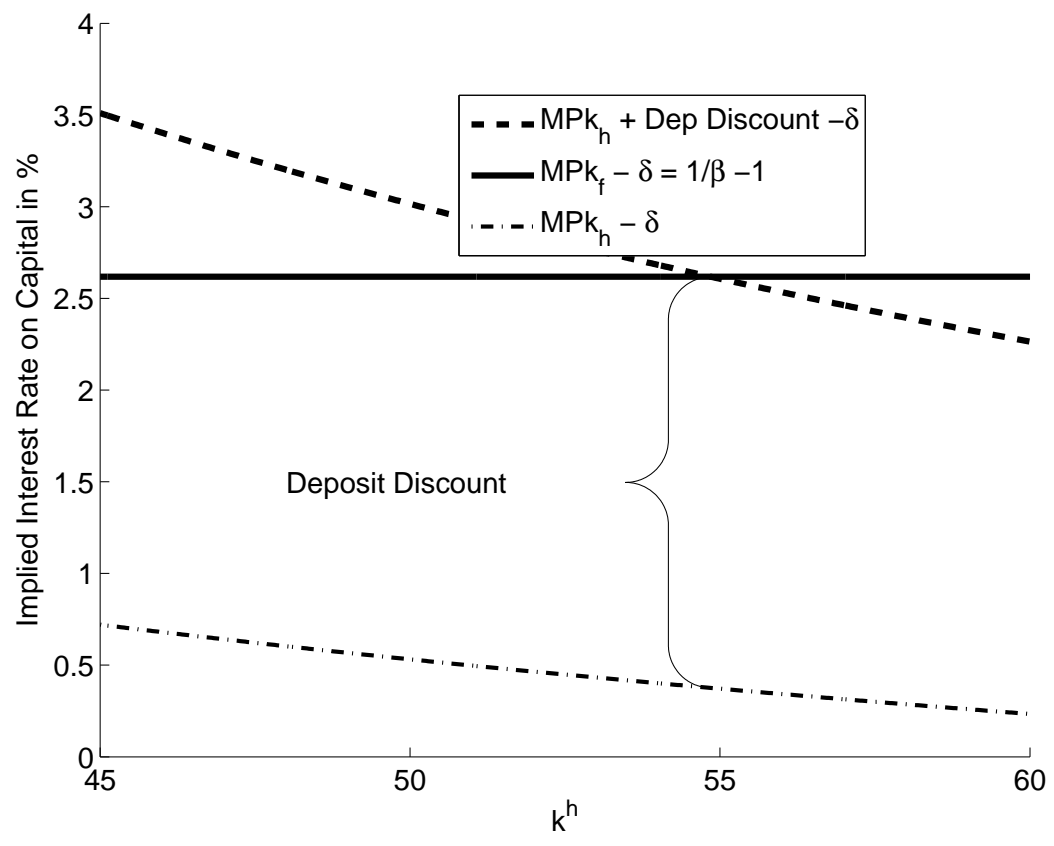

Figure 4: Optimal Level of Risked Based Capital Ratio

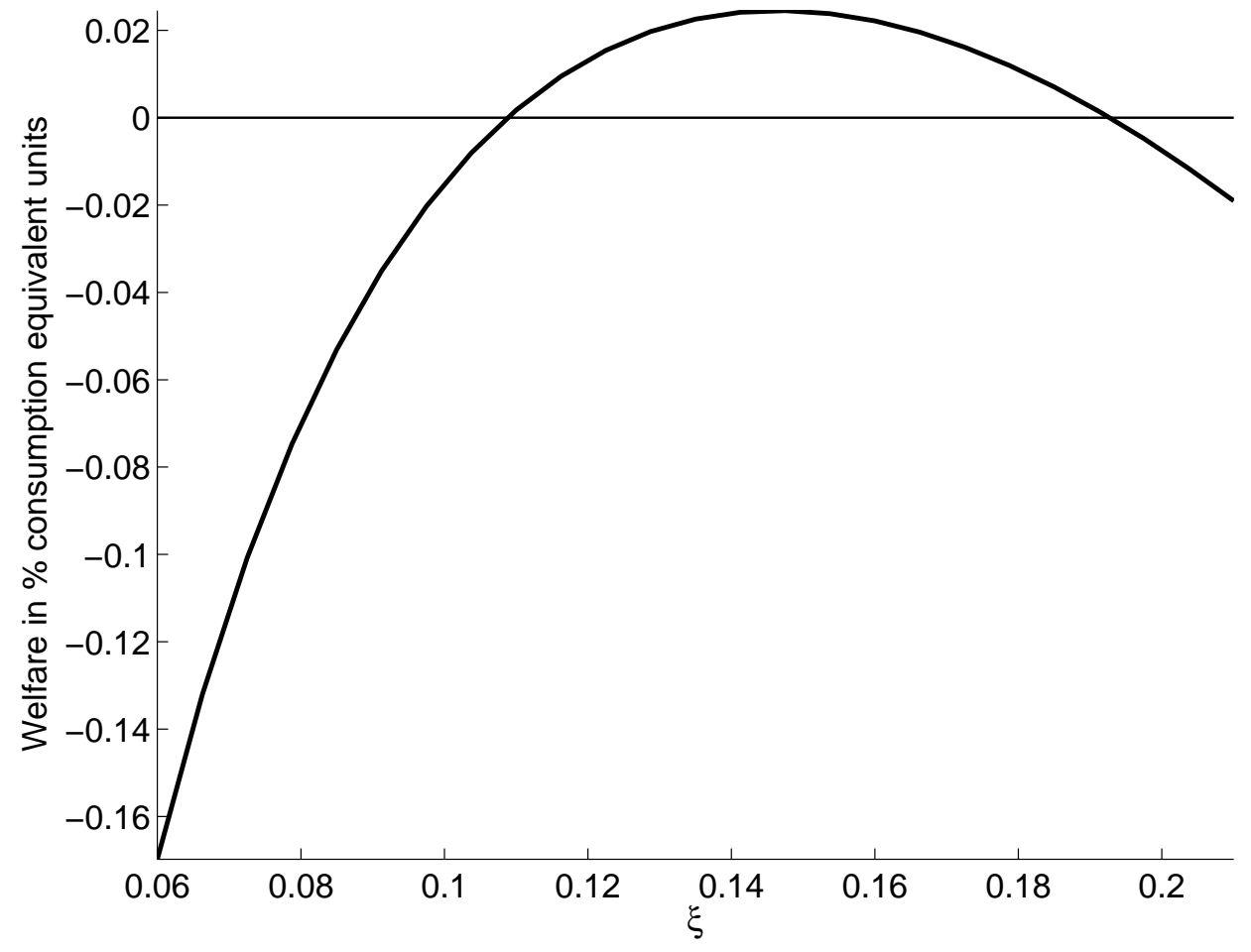


Figure 5: Funding Cost Differential Between old And NeW policy After INTRODUCTION

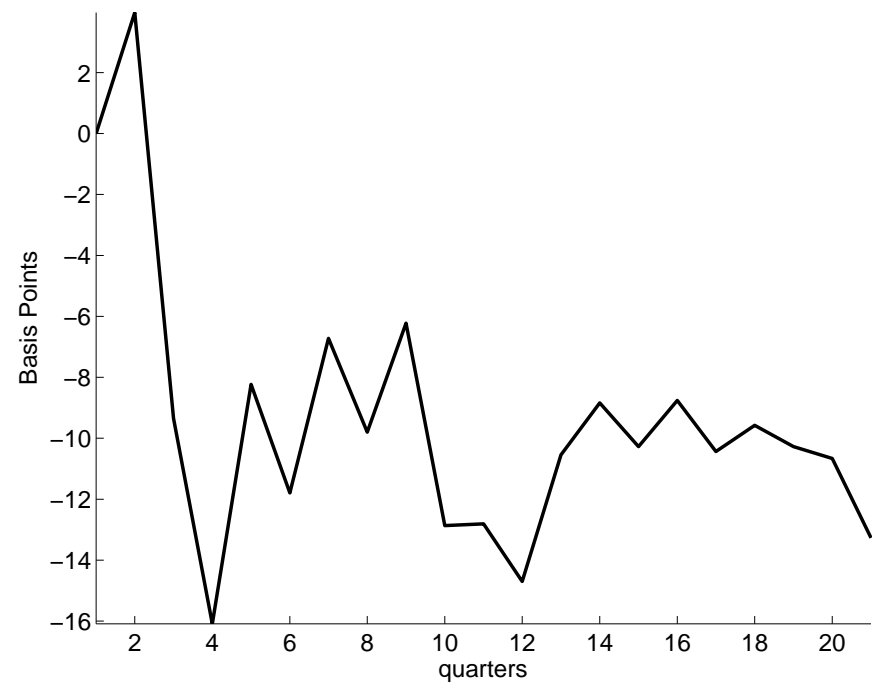

Figure 6: Welfare as a Function of the Capital Requirement Introduced DURING CRISIS VS BOOM

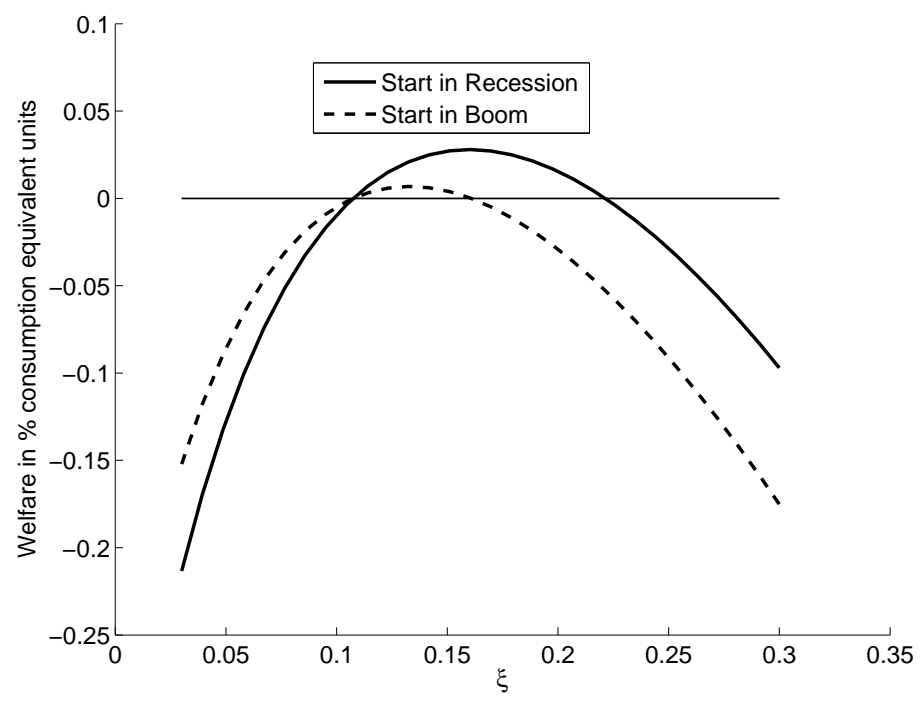


Figure 7: TRANSITIONS

BANK DEBT
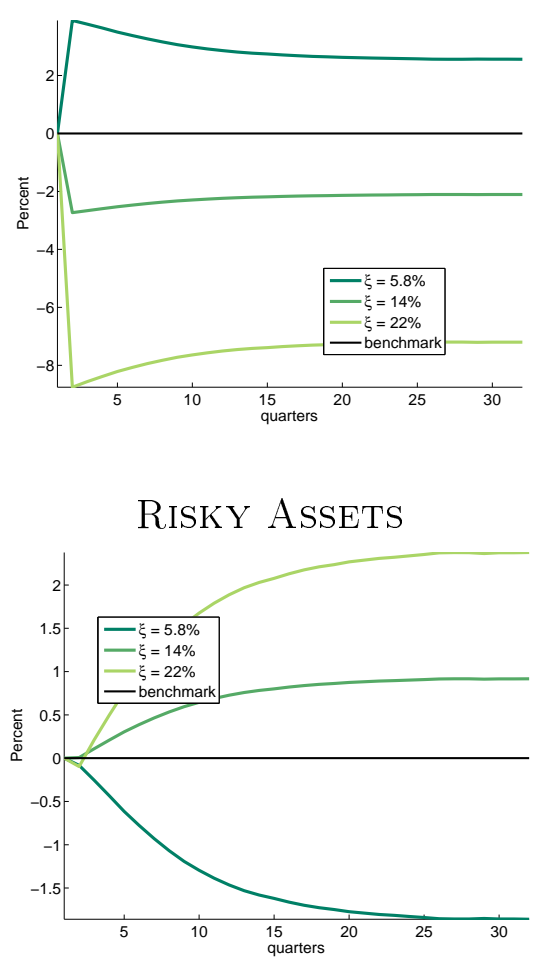

Consumption

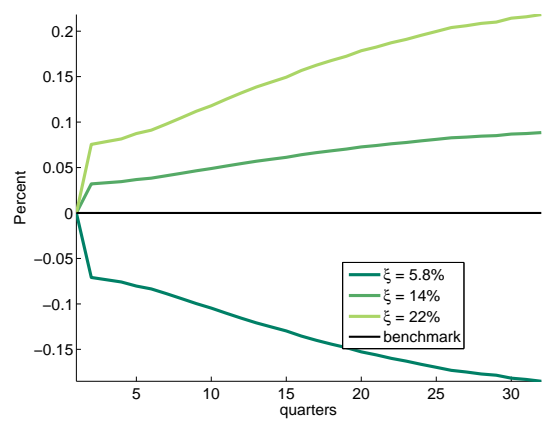

EQUITY

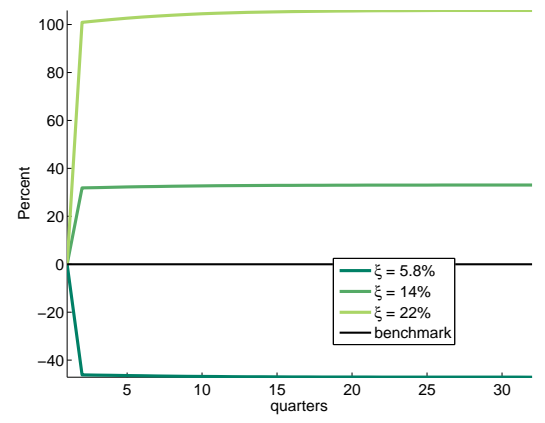

FIRM CAPITAL

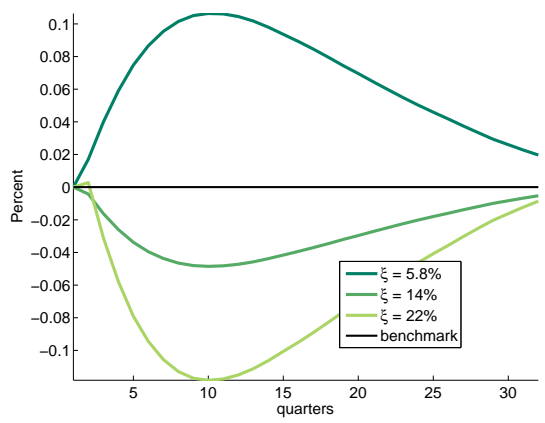

RISK-TAKING

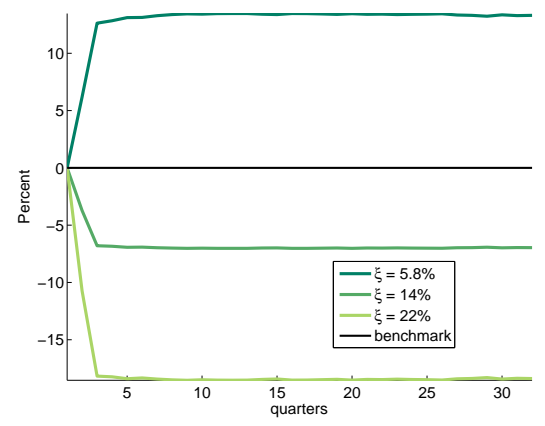

